Acta Theriologica 38 (2): 199 - 232, 1993.

PL ISSN 0001 - 7051

\title{
Rodent population dynamics in a primeval deciduous forest (Białowieża National Park) in relation to weather, seed crop, and predation
}

\author{
Zdzisław PUCEK, Włodzimierz JEDRZEJEWSKI, \\ Bogumiła JEDRZEJEWSKA and Michalina PUCEK
}

Pucek Z., Jedrzejewski W., Jedrzejewska B. and Pucek M. 1993. Rodent population dynamics in a primeval deciduous forest (Bialowieza National Park) in relation to weather, seed crop, and predation. Acta theriol. 38: $199-232$.

Population dynamics of forest rodents, bank voles Clethrionomys glareolus (Schreber, 1780) and yellow-necked mice Apodemus favicollis (Melchior, 1834) were studied in $1959-1991$ in the pristine mature forest dominated by hornbeam Carpinus betulus and oak Quercus robur in Bialowieza National Park (eastern Poland). The whole 33-year series, and particularly the detailed data from 1971 - 1991, were related to weather data and seed crop of hornbeam, oak, and maple Acer platanoides. Rodent numbers were very low in spring (April), then grew through summer due to reproduction. The annually highest numbers of both species were recorded in autumn. Winter mortality was on average $77 \%$ of autumn numbers of voles and $86 \%$ of mice. Multiannual variations in numbers were large; the combined numbers of voles and mice showed a regular pattern of 2 years of outbreak-crash (triggered by heavy mast production) and $4-7$ years of moderate, though variable, densities. Heavy seed crops (synchronous in oak, hornbeam and maple) occurred at 6.9-year intervals (in 1958, $1967,1976,1982$, and 1989), and were triggered by warm June - July temperature in the preceding year (bud formation year). Outbreaks of rodents were always preceded by winter breeding in mice and sometimes also in voles. Rodents reached highest numberg in autumn of the year following the mast peaks. Then, they declined rapidly over winter to extremely low numbers in the following spring, summer and autumn. Such crashes were recorded after 4 out of 5 outbreaks. In moderate years, summer and autumn numbers of rodents correlated with food-related factors (seed crop, temperature affecting vegetation biomass), whereas spring numbers were shaped by density dependent winter mortality. Summer (July) nu mbers of mice in moderale years were a direct function of spring numbers of overwintered adults $\left(R^{2}=91 \%\right)$. Autumn (Seplember) numbers of mice were determined by tree seed crop of the previous year $\left(R^{2}=32 \%\right)$. Summer numbers of voles depended on temperature in June - July $\left(R^{2}=29.5 \%\right)$, which most probably acted through an increased production of herbaceous vegetation biomass. No ambient factors were found to explain variation in autumn numbers of voles. In both species, the intensity of reproduction in autumn was inversely related to autumn numbers. In bank voles, high temperature in July Seplember was conducive to prolonged breeding. Winter mortality of rodents was density dependent ( $R^{2}=99 \%$ in mice and $92 \%$ in voles). Mast increased overwinter survival of mice but not voles. Snow cover increased survival of bank voles. Density-dependent predation was the main agent of rodent mortality in moderate years, whereas its role in outbreak-crash years has not yet been studied. The described pattern of population dynamics of forest rodents is regarded as typical for the deciduous forests with Quercus in lowland, temperate Europe. Review of literature showed that the heaviest seed crops of oaks (and beech) and the subsequent outbreaks of forest rodents occurred synchronously from Kazan region (Russia) in the north-east 
to Oxford (England) in the west. Destruction of natjve forests made the described pattern of radent population dynamics a relic that remained in scattered patches of the formerly widespread oak-hornbeam and oak-beech forests of Europe.

Mammal Research Institute, Polish Academy of Sciences, 17-230 Bialowieza, Poland (ZP, WJ, MP); Workshop for Ecology and Protection of the Natural Environment, 17-230 Bialowieza, Poland (B.J)

Key words: Apodemus flavicollis, Clethrionomys glareolus, population dynamics, outbreaks, regulation, seed crop, temperature, predation, geographic synchronization, deciduous forest, masting, Carpinus betulus, Acer platanoides, Quercus robur, Białowieza National Park, Poland

\section{Contents}

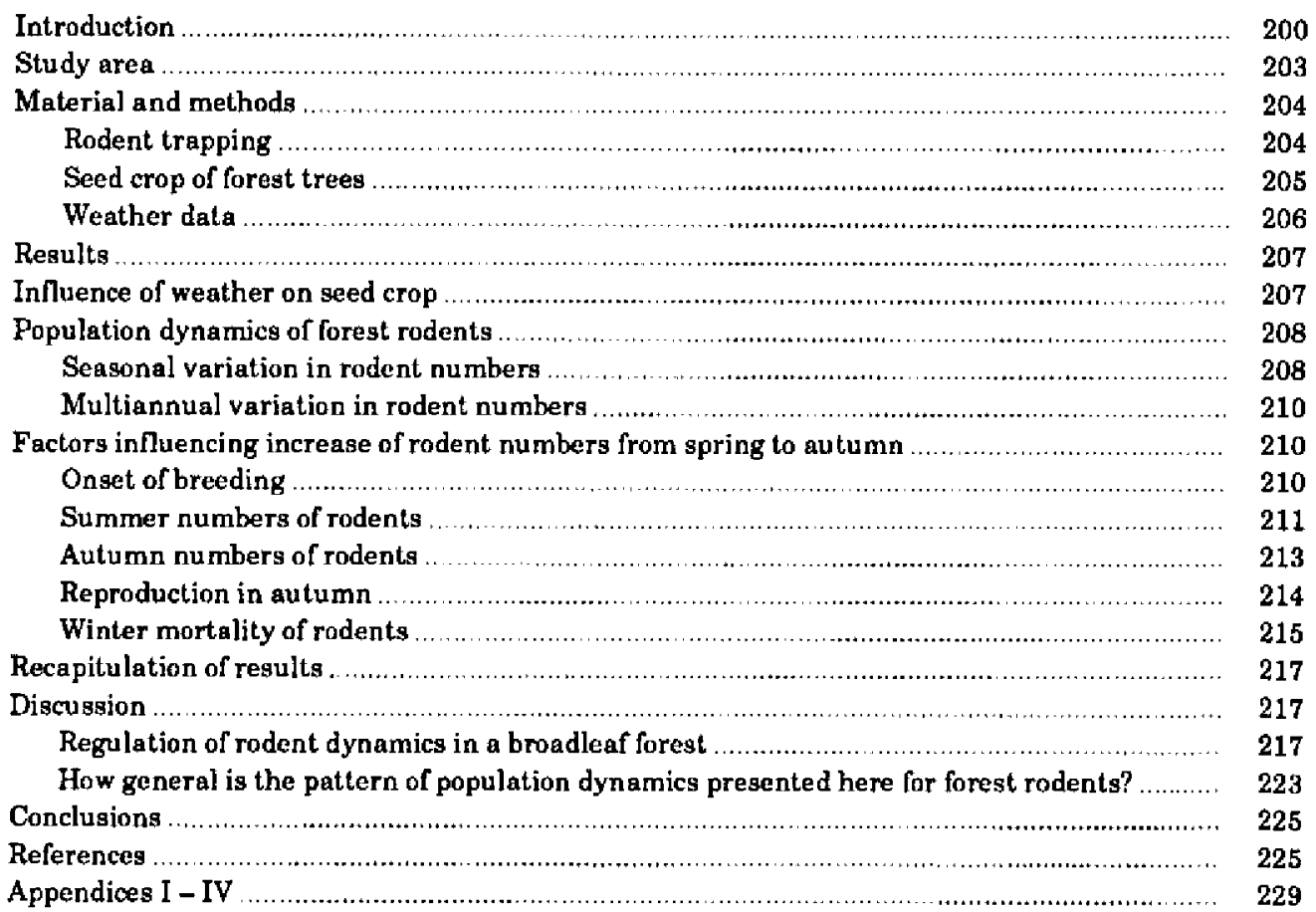

\section{Introduction}

The bank vole Clethrionomys glareolus (Schreber, 1780) and the yellow-necked mouse Apodemus flavicollis (Melchior, 1834) are the two most numerous and widespread woodland rodents in Central Europe. The European range of the bank vole includes boreal and nemoral forests (Raczyński 1983). In its habitat preferences, the bank vole is a generalist, inhabiting practically all types of forests (Pucek 1983). In its feeding habits, it is a herbivorous-granivorous rodent, regularly supplementing its diet with invertebrates (Gebczyńska 1976). Population dynamics of the bank vole varies from cyclic (3 - 5-year cycles) in northern and 
central Scandinavia to non-cyclic (with seasonal variations) further south (Hansson and Henttonen 1985).

The range of the yellow-necked mouse in Europe is restricted to deciduous and mixed forest zone (Pucek 1981). In its habitat selection, the mouse prefers deciduous forests with heavy seed species and avoids coniferous stands (Aulak 1970). It is granivorous year round and supplements its spring diet with invertebrates (Drożdż 1966, Zemanek 1972). Yellow-necked mouse populations were reported to undergo regular seasonal variations in numbers as well as irregular multiannual fluctuations (Wołk and Kozłowski 1989).

Within their common range in woodlands of Central Europe, the bank vole and the yellow-necked mouse show population dynamics patterns characterized by predominant seasonal variations and irregular multiannual fluctuations in numbers (Alibhai and Gipps 1985, Flowerdew 1985).

Among factors affecting variations in densities of 'non-cyclic' rodents, food supply, spacing behaviour and predation have been studied. Heavy seed crop of oak Quercus robur and lime Tilia cordata was followed by an outbreak of bank voles in Prioksko-Terrasnyi reserve (Moscow region) (Zablockaja 1971). Years of high mast production by beach Fagus syluatica, occurring at few-year intervals in the Danish woods caused outbreaks of the bank vole, but not of co-occurring yellow-necked mouse (Jensen 1982). On British Islands, numbers of wood mice Apodemus sylvaticus in late autumn correlated with seed fall of ash Fraxinus excelsior from October to December (Flowerdew 1985). In southern Sweden, Hansson (1971) observed that population dynamics of the wood mouse correlated with fructification of oak and beech. Rich and dependable seed crop of umbelliferous plants was thought to determine the density of wood mouse populations in Iceland (Bengtson et al. 1989a). However, the experimental removal of Umbelli. ferae from the study plot did not trigger the decline in mouse numbers, but was followed by a marked, unexpected increase in their density in the following year (Bengtson et al. 1989b).

Standing crop of herbaceous vegetation in Europe's temperate forests was estimated to be excessively greater than the food requirements of a bank vole population. Therefore, food was not regarded as a prime factor governing bank vole densities and population dynamics (Górecki and Gębczyńska 1962, Drożdż 1966). However, food can be a critical resource in spring before the start of reproduction. Aulak (1973) showed that, in early spring, the standing crop of herb layer biomass in a mature black alder Alnus glutinosa forest in the Białowieza National Park was only 8 times the food requirements of the bank vole population and, moreover, the quality of green overwintered vegetation was poor. Food manipulation experiments demonstrated that year-round provision of oats caused earlier start of breeding, higher density of bank voles in summer and autumn, but did not improve the survival of voles (Andrzejewski 1975, Bujalska 1975).

In bank voles, spacing behaviour was shown to play a role in density regulation in an island population; an exclusive territory was a prerequisite for female 

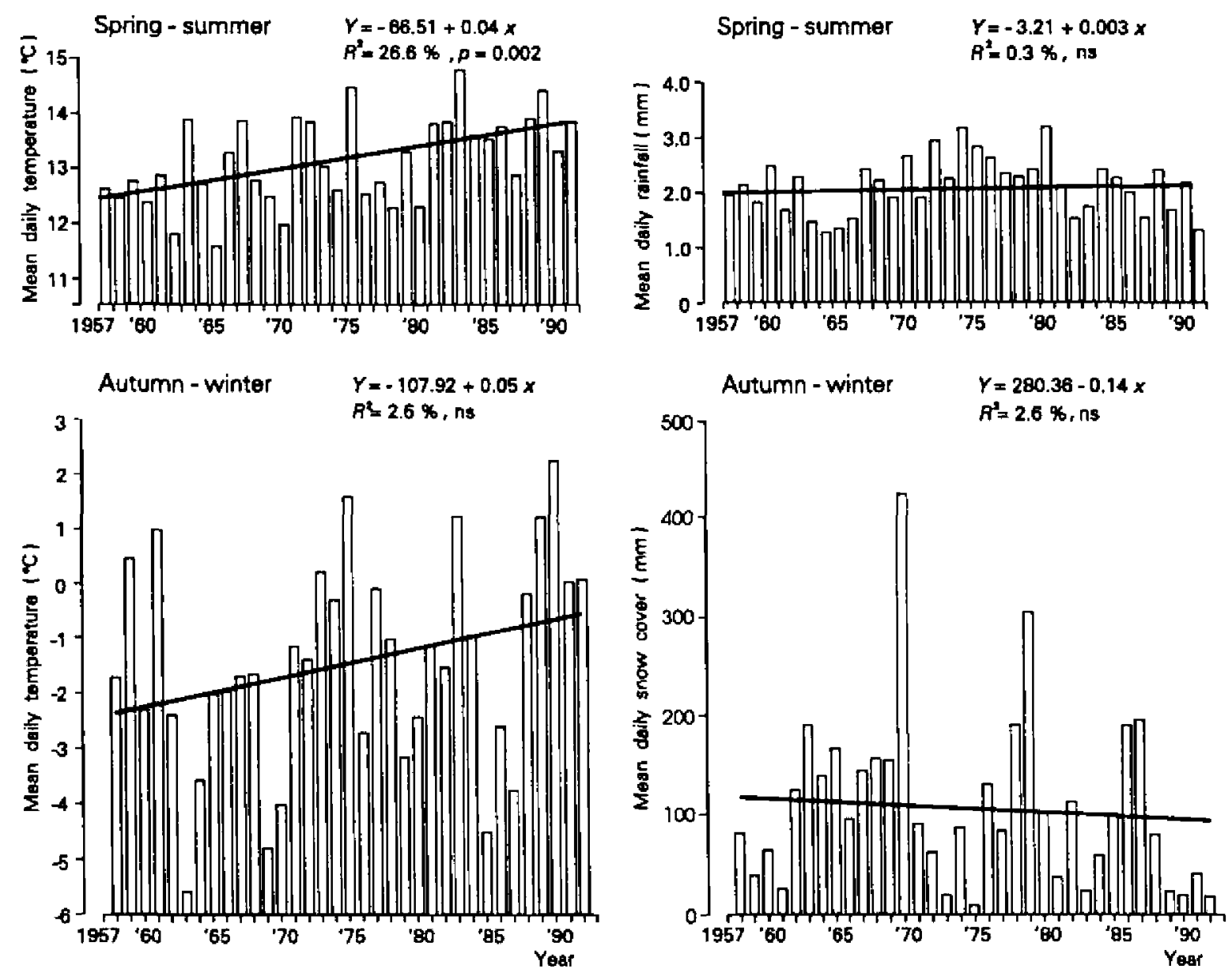

Fig. 1. Characteristics of weather of Bialowieza Primeval Forest (eastern Poland) in $1957-1991$. Upper left: mean daily temperature in spring and summer ( $1 \mathrm{Apr}-30$ Oct); lower left: mean daily temperature in autumn and winter (1 Nov -31 March); upper right: mean daily rainfall in spring and summer; lower right: mean daily snow cover in autumn and winter. Regression lines show the multiannual trends (irres pective of their statistical significance). 
maturation and breeding (Bujalska 1970). No conclusive data are available about yellow-necked mouse spacing pattern. In non-cyclic populations of both species, dispersal was most intense in spring and early summer (Gliwicz 1988). Dispersal rates correlated with the population growth rates during the breeding season and not with the densities of either voles or mice (Gliwicz 1988).

According to Erlinge et al. (1984) and Hansson and Henttonen (1988), who view rodent dynamics as community processes, central European non-cyclic populations of rodents are regulated by heavy predation exerted by generalist predators. The decisive role of predation in reducing rodent populations to low numbers every spring was evidenced by the studies on the field vole Microtus agrestis and the wood mouse Apodemus sylvaticus in southern Sweden (Erlinge et al. 1983, Erlinge 1987), on bank voles and yellow-necked mice in small woods in western Poland (Goszczyński 1977) and in Bialowieża National Park, eastern Poland (Jędrzejewski and Jędrzejewska 1993).

Generally, it seems that although factors possibly regulating rodent populations in temperate Europe are recognized, the mechanisms of their functioning are not fully understood.

The subject of this study was the multiannual population dynamics of bank voles and yellow-necked mice, variation in seed crops of the forest trees and weather in the Białowieża National Park, eastern Poland. The Park, established in 1921, and recognized as a UNESCO's Man and Biosphere Reserve (1976) and World Heritage Site (1979) has preserved the pristine mature forests, which in the largest part are shaped by natural factors. These values of Bialowieża National Park make it a model and a reference point for any ecological studies conducted in temperate Europe.

In this paper, we want to answer the questions about: (1) the pattern of population dynamics of bank voles and yellow-necked mice based on a 33-year trapping series, (2) the role of seed crop and weather in shaping various parameters of rodent populations based on a 19 to 21-year series, (3) the role of predation ( 3 years of data) on winter mortality of rodents.

\section{Study area}

Bialowieza National Park ( $=$ BNP; $52^{\circ} 43 \mathrm{~N}, 23^{\circ} 54^{\prime} \mathrm{E}$ ) of $47.5 \mathrm{~km}^{2}$ is a part of the extensive woodlands of $1,250 \mathrm{~km}^{2}$ located on the Polish-Belorussian border. The structure and character of BNP is typical of the primeval forests, unaltered by forest management, tourism, transportation, timber exploitation, or hunting. BNP includes rich, mature stands dominated by oak Quercus robur, hornbeam Carpinus betulus, lime Tilia cordata, with admixtures of maple Acer platanoides, birch Betula verrucosa and $B$. pubescens, and spruce Picea abies. Wet places with stagnated water are covered with black alder Alnus glutinosa stands with admixture of spruce. Vicinities of small forest rivers are the habital of lood-plain forest composed of ash Fraxinus excelsior, black alder, eIm Ulmus glabra, and spruce. Dry sandy soils support mixed coniferous stands with spruce, pine Pinus sylvestris and admixtures of oak, birch, and aspen Populus tremula. The regeneration and growth of saplings takes place under the canopy of old trees. The average age of all tree stands is 130 years (see Material 
and methods' for sources of data), and $81 \%$ of the forested area is covered with tree stands over 80 years old, that is mature, reproducing stands. Among those, the stands dominated by oak are most widely distributed (19.4\% of the arca), followed by hornbeam (17.2\%), spruce $(13.7 \%)$, and pine (10.9\%) stands. Detailed information on the vegetation of BNP is given by Faliniski (1986).

The climate of BNP is of transitional character, but the continental features prevail (Olszewski 1986). In 1957 - 1991, the mean daily temperature in spring - summer ( 1 Apr - 31 Oct) varied from $11.5^{\circ} \mathrm{C}$ to $14.8^{\circ} \mathrm{C}$ and showed a significant trend of warming (Fig. 1; see 'Material and methods' for sources of data). Rainfall in the warm scason ranged from $1.3 \mathrm{~mm} \mathrm{day}{ }^{-1}$ to $3.2 \mathrm{~mm}$ day ${ }^{-1}$. The mean daily temperature in autumn - winter ( $1 \mathrm{Nov}-31 \mathrm{March}$ ) ranged from $-5.6^{\circ} \mathrm{C}$ to $2.2^{\circ} \mathrm{C}$, and the mean daily snow cover from 10 to $425 \mathrm{~mm}$ (Fig. 1).

\section{Material and methods}

\section{Rodent trapping}

Rodents were sampled in the oak-lime-hornbeam forest. Removal trapping began in autumn 1958; 50 metal cylinders ( $\varphi 12-13 \mathrm{~cm}, 30 \mathrm{~cm}$ deep) and later - cones $(\varphi 13-15 \mathrm{~cm}, 45 \mathrm{~cm}$ deep) were distributed on a grid $5 \times 10 \mathrm{~m}$ and covered 0.25 ha. From the beginning till 1964 , trapping was done daily, year round. In 1965, a line of 50 snaptraps (baited with oil fried with wheat hour and placed at 10-m intervals) was added $100 \mathrm{~m}$ from the grid, and a line of 50 livetraps (baited with oats, placed at 10 -m intervals) was located $50 \mathrm{~m}$ W of the snaptrap line, parallel to it. Thus, in 1958 - 1964, only the pitfal] grid was operated and in 1965-91, rodents were captured both on the grid and the 2 lines.

In $1965-1970$, the trapping area was operated twice a year: in spring (31 - 59 days in April/May) and in autumn (44-47 days in September/October). Since 1971, three series of removal trapping were

Table 1. Age composition of yellow-necked mice Apodemus flavicollis and bank voles Clethrionomys glareolus captured in spring after winters with and without winter breeding in Biatowieza National Park. Bank vole age classes (according to $\mathrm{M}_{1}$ root length): I - 0-2 months, II - 2-4, III - 4-6, IV -6-8, V - 8-10, and VI $+>10$ months. Percent distributions of age classes in years with and without winter breeding are significantly different: mice $-G=36.3, \mathrm{~d} \Gamma=5$, $p<0.001$; voles $-G=55.7, \mathrm{df}=5, p<0.001$.

\begin{tabular}{|c|c|c|c|c|c|c|}
\hline \multirow{2}{*}{$\begin{array}{l}\text { Total number } \\
\text { of rodents }\end{array}$} & \multicolumn{6}{|c|}{ Percent of mice in body weight classes (g): } \\
\hline & $<14$ & $14.1-19$ & $19.1-24$ & $24.1-29$ & $29.1-34$ & $>34$ \\
\hline \multicolumn{7}{|c|}{ Springs after winter breeding $(1975,1977,1983,1990)$} \\
\hline$n=135$ & 27 & 13 & 7 & 8 & 12 & 33 \\
\hline \multicolumn{7}{|c|}{ All other springs ( 17 years) } \\
\hline \multirow[t]{3}{*}{$n=117$} & 12 & 1 & - & 13 & 22 & 52 \\
\hline & \multicolumn{6}{|c|}{ Percent of bank voles in age classes: } \\
\hline & I & II & III & IV & $\mathrm{V}$ & VI+ \\
\hline \multicolumn{7}{|c|}{ Spring after winter breeding (1990) } \\
\hline$n=157$ & 14 & 18 & 4 & 9 & 22 & 33 \\
\hline \multicolumn{7}{|c|}{ All other springs (20 years) } \\
\hline$n=332$ & 1 & 1 & - & 4 & 20 & 74 \\
\hline
\end{tabular}


conducted each year; spring series lasted $43-47$ days (from 15 April), summer $-28-31$ days (from 1 July), and autumn - 30-47 days (from 15 September). The entire 33-year data set (1959 - 1991) was used for a general description of rodent dynamics. Total numbers of rodents caught each year in 1959 - 1964 and 1965 - 1970 are presented as percent of the maximum recorded rumbers (in 1959 and 1968, respectively). Before the calculation of percentages, the totals of each year were corrected for the uneven lengths of the trapping series. The material from $1971-1991$ was analysed in detail and correlated with weather factors and seed crop. For this purpose, we arbitrarily used only the first 21 days of each trapping series to make the results of all series comparable.

For the 21-year data (1971-91), the total numbers of yellow-necked mice and bank voles caught by all types of traps during each trapping serie were recalculated into $n$ rodents/100 traprights (data listed in Appendices I and II). In order to identify the juvenile bank voles in spring, the length of $\mathrm{M}_{1}$ roots was measured. The individuals with an average root length $<0.15 \mathrm{~mm}$ were classified as young up to 4 months (cf Pucek and Zejda 1968). In yellow-necked mice, body mass was an age criterion; individuals weighing less than or equal to $24 \mathrm{~g}$ in spring trapping were classified as young. This criterion was based on the detailed analysis of frequency distribution in body mass classes (Table 1 ).

Bank voles and yellow-necked mice constituted, respectively, 44 and $41 \%$ of all small mammals caught in 1971 - 1991. Only these two species, hereafter referred to as rodents, were subject of this study. During the entire 33-year trapping, 16 other species of small mammals were captured: Sorex araneus, S. minutus, S. caecutiens, Neomys fodiens, $N$. anomalus, Talpa europaea, Apodemus agrarius, Pilymys sublerraneus, Microtus agrestis, $M$. arvalis, $M$. oeconomus, Micromys minutus, Sicista betulina, Dryomys nitedula, Glis glis, and Mustela nivalis.

\section{Seed crop of forest trees}

We used two sources of information about seed crop. The data on hornbeam and maple (collected by the Białowieta Geobotanical Station of Warsaw University and kindly granted to us by Prof. J. B. Falinski) were gathered in BNP on three permanent plots located in the rich deciduous (oak-lime-maple-hornbeam) forest and established for the longterm research on vegetation differentiation. Each sample plot $(50 \times 2 \mathrm{~m})$ was divided into 25 squares, $2 \times 2 \mathrm{~m}$ each. Since 1972 , the forest foor in the center of each square on each plot was photographed $\left(75\right.$ photos, each picturing $0.50 \mathrm{~m}^{2}$ of the forest floor, taken with a color diapositive $35 \mathrm{~mm}$ film) at 5-day intervals from 1972 to 1989 , and at 10-day intervals in 1990. The detailed description of the sampling plots and sampling technique is given by Falifiski (1977). For the estimation of seed crop, we used two series of photographs (late October and early November) from cach year (1972 - 1990). The choice was determined by the time when seeds most intensely fell on the ground and were best visible. Using a projector (reading apparatus DL-2) with $17.5 \times$ enlargement, we counted all seeds of hornbeam and maple on squares numbered $1,4,7$, $10,13,16,19,22$ and 25 along each plot. One count covered $13.5 \mathrm{~m}^{2}$, but the total numbers of seeds counted in the two series in each year were averaged, recalculated into $n$ seeds $/ 10 \mathrm{~m}^{2}$, and used as an index of seed crop in a given year (data in Appendix III).

Data on oak and spruce seed crop in 1975 - 1990 were provided by the Bialowieza Forest Administration (see Appendix III). The indices of crops (in kilograms) were the annual purchases (for replantation purposes) of acorn and cones from the local people, who gathered them in the exploited part of Białowieza Primeval Forest. The amount of acorn and cones gathered by people depended primarily on seed crop, but it might also have been influenced by current prices. We think that the latter factor caused serious underestimate of crop in 1989 only, when very low prices (due to inflation) discouraged the collectors. Based on our own observations, we assessed the 1989 acorn crop as superabundant. [Note: Adamczewska (1961) and Wołk and Kozłowski (1989) have also used data from the Forest Administration. However, they have mistaken the financial year, in which the seed purchase was recorded, for the true crop year. As a result, they cited the figures with 1-year delay in relation to real crop year]. 
Tree stands dominated by oak, hornbeam, maple, and spruce covered $54 \%$ of all forested terrain of BNP, and formed $66.5 \%$ of all stands over 80 years of age. Data on tree species and age structure of BNP forests were taken from the elaboration (maps and text) of Forest Inventory of BNP. The inventory was conducted in the late $1980 \mathrm{~s}$ by team of specialists from the Ofice of Forest Inventory and Geodesy in Bialystok, according to the standard methods used in Polish forestry.

\section{Weather data}

Weather data from 1957 through 1991 were obtained from the Białowieza Meteorological Station and included mean daily temperature $\left({ }^{\circ} \mathrm{C}\right)$, rainfall $(\mathrm{mm})$, and snow cover $(\mathrm{mm})$. The mean daily temperature was calculated as a mean of morning $(0700 \mathrm{~h})$, noon $(1200 \mathrm{~h})$, and doubled evening (1900 h) records. These mean daily measures were averaged for longer periods for correlations with various biological parameters. Weather data (1971 - 1991) are listed in Appendix IV.

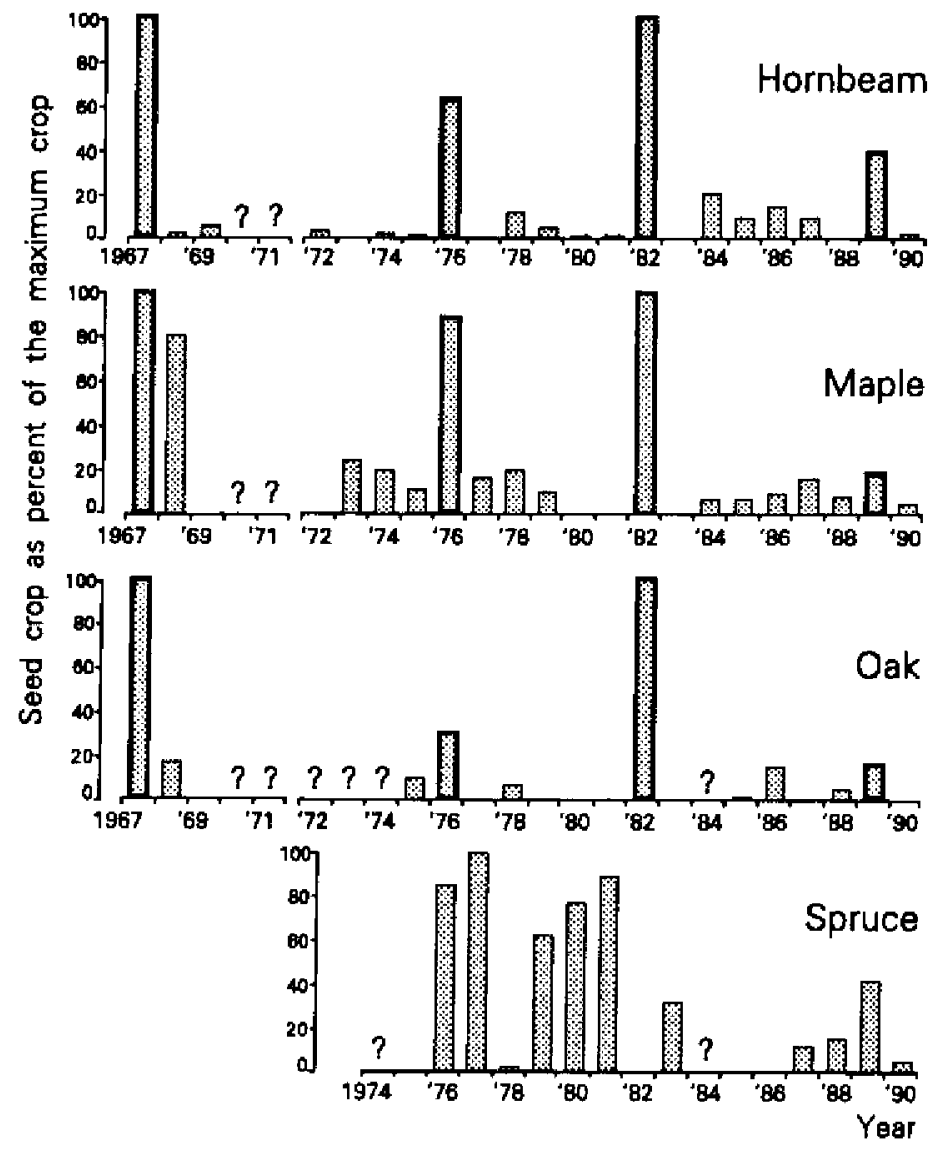

Fig. 2. Multiannual variation in seed crop of hornbeam Carpinus betulus, maple Acer platanoides, oak Quercus robur, and spruce Picea abies in Białowieza Primeval Forest. To standardize the scale, the maximum recorded crop of each species was taken as 100, and crops in other years were shown as percent of the maximum crop. ? - no data. Original dala (1972 - 1990) are listed in Appendix III. Data for 1967 - 1969 are calculated from Falińska (1971). Heavy mast production synchronous in the three deciduous species marked by thick lines. 


\section{Results}

\section{Influence of weather on seed crop}

From 1972 to 1990 , hornbeam, oak, and maple produced three heavy seed crops at 6 and 7 -year intervals. During the intervening years the crops were small and irregular (Fig. 2). Fructification pattern of the three species was highly synchronized (hornbeam-maple: $r=0.91$; hornbeam-oak: $r=0.93$; maple-oak: $r=0.87$, $p<0.0005$ for all correlated pairs). Spruce showed a different rhythm of seed production (Fig. 2). The cone crop did not correlate with seed crop of the deciduous trees ( $p>0.5$ for all pairs). From 1957 to 1971 (period not covered by our seed data series), two mast years were reported: in 1958 (Adamczewska 1961; but see note in 'Material and methods') and in 1967 (Falińska 1971).

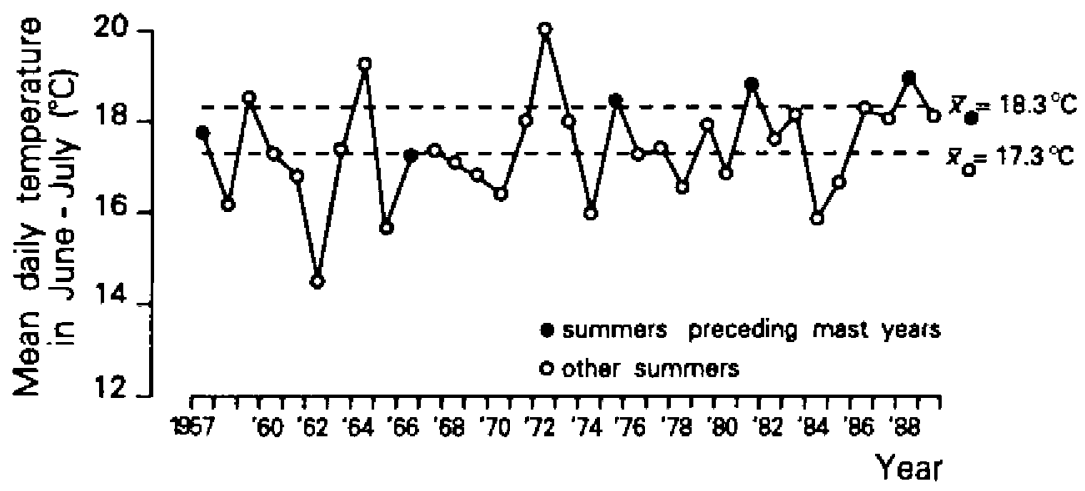

Fig. 3. Mean daily temperature in June - July in su mmers preceding mast years (i.e. summers, when trees form flower buds) and all other summers in 1957 - 1989. Statistical comparison of average values for closed and open points: $t=1.815, \mathrm{~d} f=31, p=0.079$ (Student $t$-test).

All studied species of trees form flower buds in summer of the year preceding flowering and fruiting. Thus, the seed crops can be affected by weather in two years (bud formation and seed formation). The five heavy crops observed in BNP $(1958,1967,1976,1982,1989)$ were stimulated by the high mean temperature of June - July during the prior year (Fig. 3). In the 19-year series of detailed data, the seed crop of deciduous trees in year $n$ showed a tendency to correlate negatively with rainfall during the same summer (hornbeam: $R^{2}=32 \%, \mathrm{df}=16, p=0.015$; maple: $R^{2}=23 \%$, df $=17, p=0.05$; oak: $R^{2}=20 \%$, df $=13, p=0.094$, ns). In spruce, no such correlation was recorded $\left(R^{2}=2.6 \%, p=0.55\right)$. 


\section{Population dynamics of forest rodents}

\section{Seasonal variation in rodent numbers}

Population dynamics of both the yellow-necked mouse and the bank vole (studied in detail in 1971 - 1991) were characterized by clear seasonal variations in numbers (Figs 4 and 5 ). The lowest numbers of rodents were recorded in spring (April). In the yellow-necked mouse, they averaged 0.265 overwintered adults $/ 100$ trapnights (SD $0.25, n=21$, range $0.03-0.86$ ) and in the bank vole 0.69 adults $/ 100$ trapnights (SD $0.8, n=21$, range $0-3.37$ ). Rodents captured in spring were nearly exclusively overwintered adults; juveniles were caught in some years only and in low numbers (Appendices I and II).

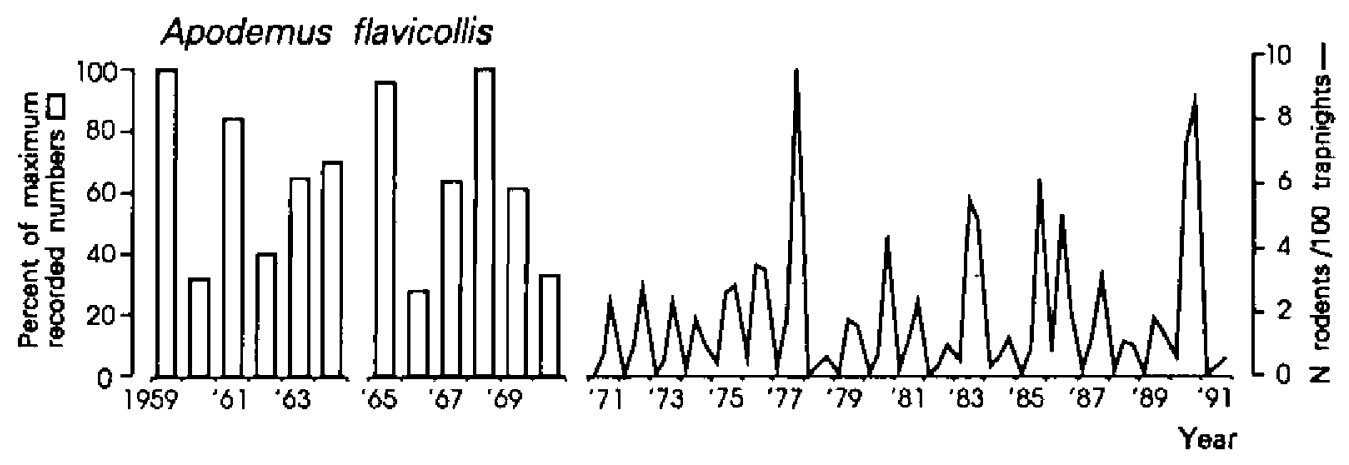

Fig. 4. Population dynamics of the yellow-necked mouse Apodemus favicollis in Białowieza National Park in 1959 - 1991. Three series (varying in methods of trapping but conducted in one permanent plot) are presented. In $1959-1964$ and 1965 - 1970, the total number of mice captured throughout each year is presented as percent of maximum numbers (recorded in 1959 and 1968, respectively). In 1971 - 1991 (data in Appendix I), three points for each year are marked: spring (the lowest yearly numbers - April/May, only overwintored adults shown), summer (July), and aulumn (Sept/Oct). See 'Material and methods' for details on trapping schedule.

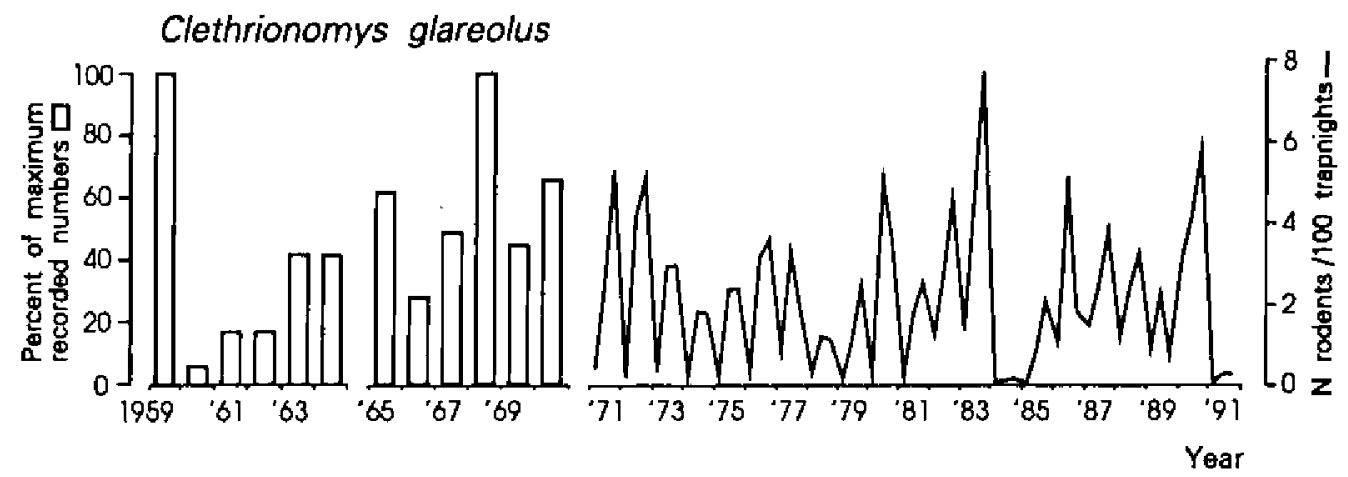

Fig. 5. Population dynamics of the bank vole Clethrionomys glareolus in BNP in $1959-1991$. Explanations as in Fig. 4. Data from 1971-1991 in Appendix II. 
Throughout spring and summer, rodents always grew in numbers due to reproduction. The average index of summer (July) abundance of mice was 1.9/100 trapnights (SD 1.92, range $0.29-7.30$ ), that of bank voles $-2.4 / 100$ trapnights (SD 1.39, range $0.10-5.09$ ). The numbers of rodents most often continued to grow till autumn. In mice, the indices of autumn numbers were lower than those in summer in only 7 years out of 21-year series (Fig. 4). In voles, only 6 indices of autumn abundance were lower than or equal to the summer ones (Fig. 5). Generally, the average autumn numbers were the highest. The mean index of autumn abundance was 3.0 (SD 2.5, range $0.55-9.62$ ) in the yellow-necked mouse and 3.0 (SD 1.9, range $0.13-7.71$ ) in the bank vole.

If we take the total increase in rodent numbers from spring to autumn trapping (calculated as the difference between mean autumn number and mean number of overwintered adults earlier in spring) as $100 \%$, then bank vole numbers increased significantly more from spring to summer (on average $72 \%$ ) than from summer to autumn (28\%) $(G=20.04, \mathrm{df}=1, p<0.001)$. In mice, the increase from spring to summer contributed on average $60 \%$ to the total increase, and that from summer to autumn $-40 \%(G=4.02, \mathrm{df}=1, p<0.05)$. Voles and mice did not differ in the seasonal allocation of their population increase ( $G=3.22, \mathrm{df}=1, p>0.05$ ).

Every winter, except for $1989 / 90$, there was a clear decline of rodent numbers. In 1989/90, winter reproduction of bank voles was recorded. However, the apparent 'increase' of adults in 1989/90 denoted in Fig. 5 resulted from very low trappability of rodents in autumn 1989, when superabundant acorn presumably made the trap baits nonattractive to voles. Therefore, winter $1989 / 90$ was excluded from mortality analysis. If we accept the difference between the autumn and the next spring

\section{Apodemus flavicollis and Clethrionomys glareolus}

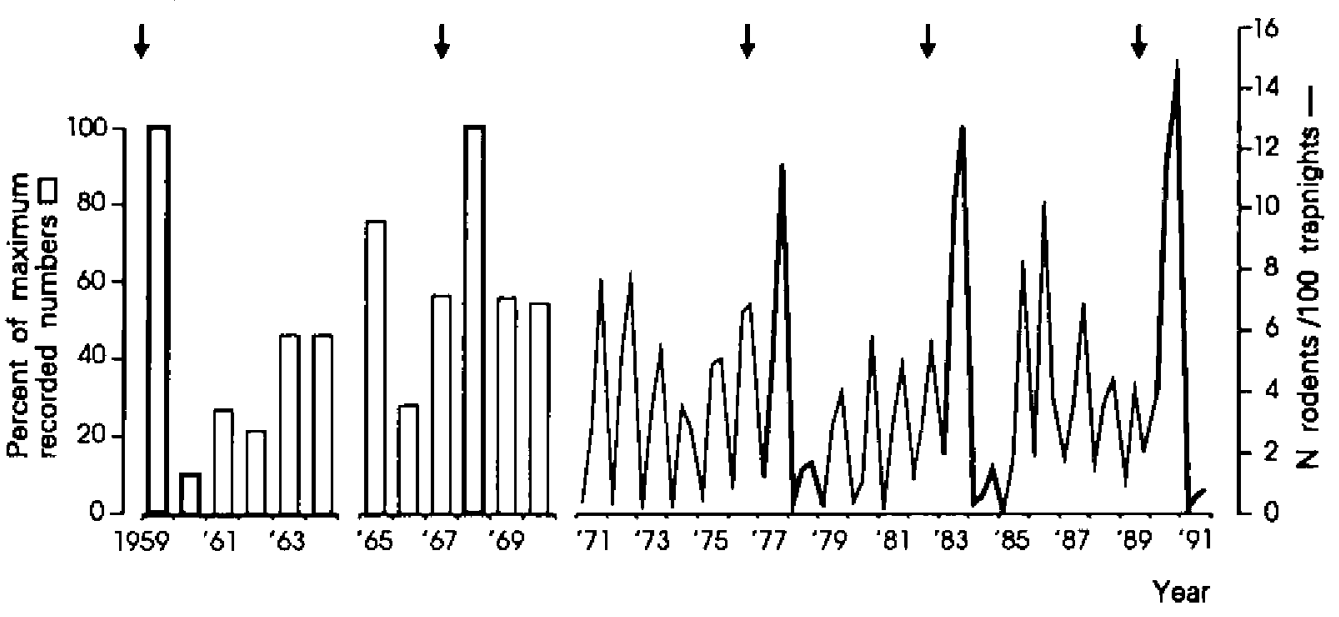

Fig. 6. Indices of combined numbers of yellow-necked mice and bank voles in BNP. Arrows: heavy seed crops of deciduous trees (see Fig. 2). Rodent dynamics divided into outbreak and crash years (2 years following heavy seed crops) - thick line, and moderate years (all other years) - thin line. Indices of numbers as in Figa 4 and 5. 
indices of rodent abundance as a measure of winter mortality, then on average $86 \%$ of mice (SD 17.3, range $33.3-99.3, n=19$ ) and $77 \%$ of voles (SD 22.5, range $17.2-100, n=19$ ) disappear throughout winter. No significant difference between vole and mouse mortality in winter was found ( $G=0.50, \mathrm{df}=1, p>0.1)$.

\section{Multiannual variation in rodent numbers}

In addition to regular seasonal changes in numbers, both species showed marked between-year variations of numbers. In $1959-1970$, the standardized annual indices of rodent abundance varied up to 17 times in voles and 4 times in mice. The autumn indices of abundance in $1971-1991$ varied as much as 61 -fold in bank voles and 17-fold in yellow-necked mice (Figs 4 and 5).

The combined numbers of both species show a clear pattern of multiannual changes (Fig. 6). The extraordinarily high numbers (outbreaks) occurred one year after the high mast years. Four of 5 outbreaks were followed by rapid winter decline and one year of very low numbers (crash years). All other years were characterized by intermediate (moderate) numbers of rodents.

The analysis of cyclicity indices (after Hansson and Henttonen 1985) calculated for autumn abundances in 1971 - 1991 showed, that 15 moderate years were characterized by very low values (vole -0.21 , mouse -0.24 ), typical of stable populations. In contrary, six outbreak-crash years (two years after each mast year) were characterized by high cyclicity indices ( 0.71 in voles and 0.57 in mice), typical of cyclic populations. These indices calculated for the entire 21-year series were 0.43 in voles and 0.35 in mice. In the further analysis, the tentative distinction between the years of moderate and outbreak-crash densities of rodents will be followed.

Factors influencing increase of rodent numbers from spring to autumn

\section{Onset of breeding}

Out of 21 years of the trapping in April, juvenile yellow-necked mice were captured in 10 years, including 4 years with winter breeding and 6 years with an early onset of reproduction (Fig. 7). Three springs following the high mast years were characterized by the mean juvenile abundance 12 times higher $(\bar{x}=0.561$, SD $0.018, n=3$ ) than the average for all other years $(\bar{x}=0.047$, SD $0.082, n=$ 18). In multiple regression, hornbeam seed crop (as representative of all 3 species of deciduous trees) of the preceding autumn and the mean daily temperature in March explained $78 \%$ of variation in the number of juvenile mice caught in spring ( $n=19, p<0.0005, s r^{2}=0.504$ for hornbeam seed crop, $s r^{2}=0.129$ for March temperature). Winter breeding occurred after autumns of mast fall (1976/77, 1982/83, 1989/90) and in 1974/75 (Table 1). Apart from 3 outbreak years, there was no correlation between the number of juveniles in spring and the number of adult mice $(r=0.30, p=0.23, n=18)$. 


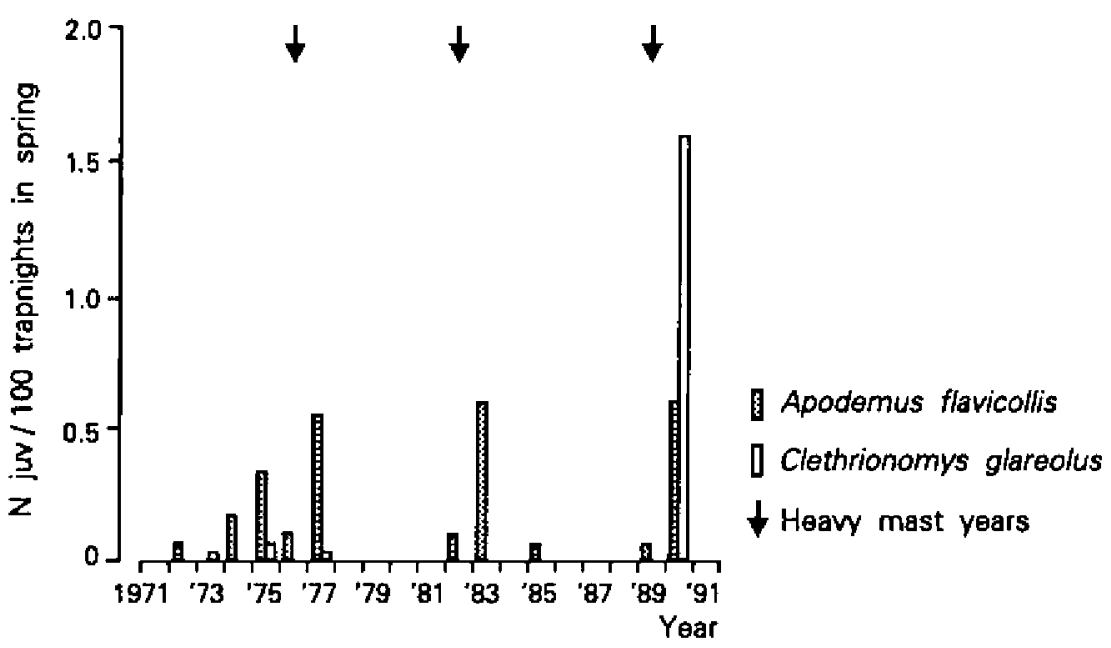

Fig. 7. Numbers of juvenile yellow-necked mice and bank voles recorded in spring (April) in 1971- 1991.

Bank voles did not respond to the superabundance of seeds by winter breeding, except for winter 1989/90, when 1.6 juv/100 trapnights were caught (Fig. 7). Springs, when juvenile voles were captured, were preceded by much warmer winters (mean daily temp. $+1^{\circ} \mathrm{C}, n=4$ ) than springs with no early reproduction (mean temp. $-1.5^{\circ} \mathrm{C}, n=17$ ). Winter $1989 / 90$ was the warmest of all (mean temp. $+2.2^{\circ} \mathrm{C}$ ). Winter breeding of voles was recorded in $1989 / 90$ only, when heavy seed crop coincided with exceptionally warm winter (Table 1).

\section{Summer numbers of rodents}

In moderate years, variation in summer numbers of mice was nearly fully explained by the spring numbers of overwintered adults (Fig. 8). In outbreak and crash years, summer numbers did not depend on the numbers of overwintered adults in spring. In crash years, summer numbers of mice were lower than in other years characterized by equally poor seed crop, although the difference was statistically not significant (Table 2).

Summer numbers of bank voles could be predicted by two factors: the number of overwintered adults in spring (much weaker correlation than with yellow-necked mice though) and the mean daily temperature in June - July (whole series $n=$ $21, R^{2}=48.5 \%, p<0.003, s r^{2}=0.30$ for number of adults and $s r^{2}=0.17$ for temperature in June - July). Addition of hornbeam seed crop to the multiple regression model increased $R^{2}$ very little $\left(R^{2}=54.8 \%, p=0.003, n=19\right)$. In moderate years, summer numbers of bank voles were primarily related to temperature of June - July $\left(R^{2}=29.5 \%, p=0.036, n=15\right.$; Fig. 9). In outbreak years, the summer numbers were determined by both seed crop and temperature. In crash years, neither the temperature nor the poor supply of seeds were sole causes of low summer numbers of voles (Fig. 9, Table 2). 


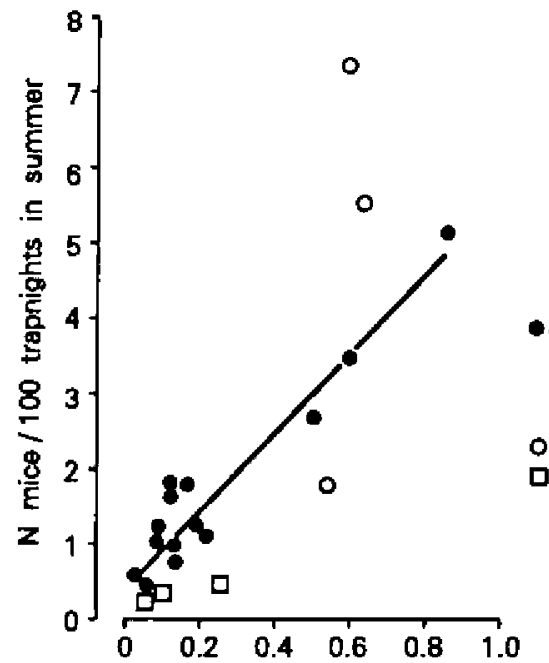

$\mathrm{N}$ adults / 100 trapnights in spring
- moderate years

$Y=0.456+5.136 x$

$R^{2}=91 \%, p<0.0005$

o outbreak years

crash years

Fig. 8. Relationship between the number of overwintered adult yellow-necked mice captured in spring (April) and the total number of mice in summer (July). Regression calculated for moderate years.

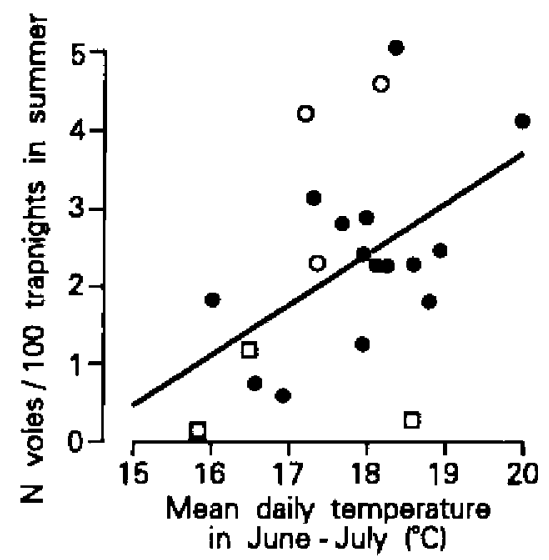

\section{- moderate years \\ $Y=-9.215+0.647 x$ \\ $R^{2}=29.5 \%, p=0.036$ \\ - outbreak years \\ 口 crash years}

Fig. 9. Relationship between the number of bank voles in summer (July) and the mean daily temperature in June - July. Regression calculated for moderate years.

Table 2. Comparison of summer and autumn numbers of yellow-necked mice and bank voles ( $n / 100$ trapnights) in the years $(1978,1984,1991)$ after nil seed crop (of oak, hornbeam, and maple) following the heavy crops, and in years $(1980,1981,1982)$ after nil crops not preceded by heavy crops (data in Appendices I, II and III).

\begin{tabular}{lcc}
\hline Season & \multicolumn{2}{c}{ Number of rodents, mean (SD) } \\
\cline { 2 - 3 } & $\begin{array}{c}\text { Nil seed crop after heavy crop } \\
\text { (year } n \text { ) }\end{array}$ & $\begin{array}{c}\text { Nil seed crop in other years } \\
\text { (year } n \text { ) }\end{array}$ \\
\hline Mice in summer (year $n+1)$ & $0.36(0.10)$ & $0.71(0.43)$ \\
Mice in autumn (year $n+1)$ & $0.80(0.41)$ & $2.27(1.27)$ \\
Voles in summer (year $n+1)$ & $0.53(0.59)$ & $1.83(0.93)$ \\
Voles in autumn (year $n+1)$ & $0.52(0.54)$ & $3.85(1.16)$ \\
\hline
\end{tabular}


Although determined by partly different intrapopulation and environmental factors, the summer numbers of mice and voles were mutually correlated in the whole series $(r=0.69, p<0.01, n=21)$ and in moderate years only $(r=0.54, p$ $=0.039, n=15$ ).

\section{Autumn numbers of rodents}

In both species, the increase in numbers from summer to autumn (calculated as the difference between autumn and summer indices of numbers) negatively correlated with the increase from spring to summer during 15 moderate years $(r=$ $-0.71, p=0.003$ in mice, $r=-0.58, p=0.024$ in voles). High summer increase was followed by slow or even negative autumn increase and vice versa (Figs 4 and 5).

In mice, this relationship was modified by the seed crop in the previous year, which enhanced the autumn increase in moderate years $\left(R^{2}=66.4 \%, p=0.004\right.$, $n=13)$ and in the whole series $\left(R^{2}=39 \%, p=0.019, n=19\right.$; multiple regression for autumn increase as dependent variable and summer increase and hornbeam seed crop as independent variables).

In bank voles, variation in seed crop in moderate years did not influence the autumn increase. It did so, however, in high mast years (Fig. 5). In the whole series with mast years included, hornbeam seed crop and summer increase explained $31 \%$ of variation in bank vole autumn increase ( $p=0.05, n=19)$.

In both species, the autumn increase negatively correlated with autumn reproduction index (calculated as percent of females with visible pregnancies and juveniles in the total number of rodents captured in autumn). This correlation,

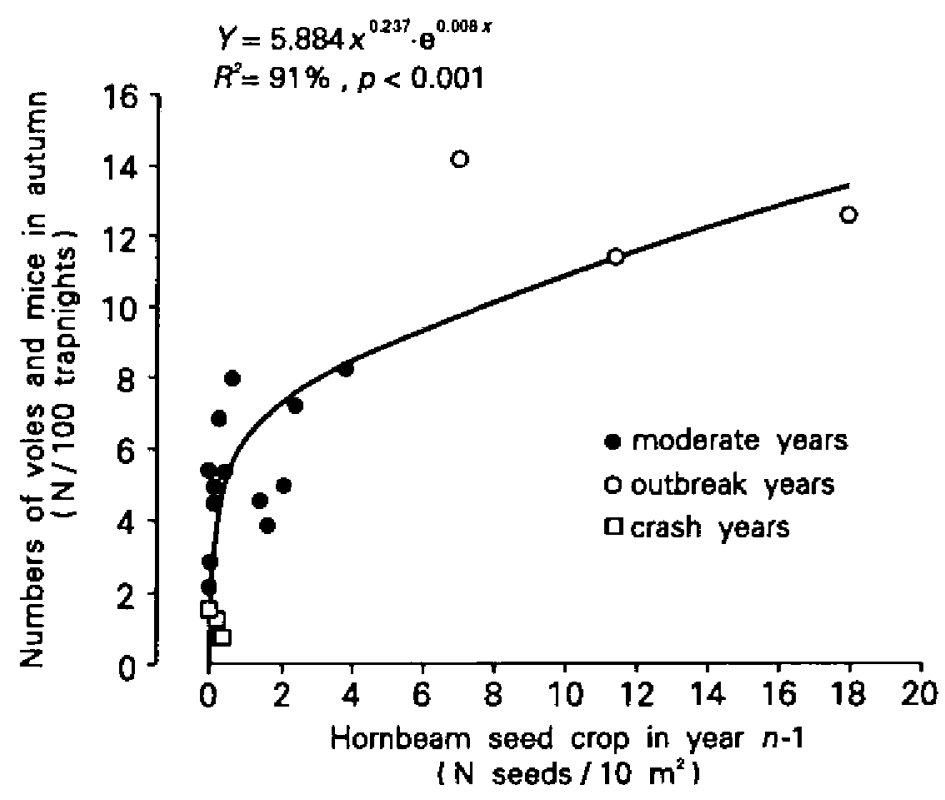

Fig. 10. Relationship between the combined autumn numbers of yellow-necked mice and bank voles and hornbeam seed crop of the previous autumn. Regression includes moderate, outbreak and crash years. 
however, was significant in mice $(p=0.019$ for the whole series, $p=0.024$ for moderate years) and not in the bank vole $(p>0.1)$.

Increase in numbers from summer to autumn in bank voles and that in mice were mutually correlated in moderate $(r=0.70, p=0.004)$ but not in outbreak-crash years.

The autumn numbers of mice depended on the hornbeam seed crop of the previous year, both in the whole series $\left(R^{2}=45 \%, p=0.002, n=19\right)$ and in moderate years only $\left(R^{2}=32 \%, p=0.045, n=13\right.$ ). In the case of bank voles, the variation in autumn indices of numbers was best explained by two factors: number of adult voles in spring and hornbeam seed crop. Both of them had positive effect on the number of voles in autumn $\left(R^{2}=54.1 \%, p=0.002, n=19\right)$. However, only the outbreak years shaped this relationship. In moderate years, autumn numbers of voles depended neither on seed crop nor on spring number of adults.

The combined autumn numbers of voles and mice were largely determined by the seed crop of the previous year (Fig. 10), and the relationship was much stronger at the community level than in each of these species separately. No significant correlation between vole and mouse autumn numbers was found $(r=0.352, p=$ $0.12, n=21$ ).

\section{Reproduction in autumn}

September - October trapping coincided with the latest phase of breeding. The index of autumn reproduction varied between years from 0 to $55.6 \%$ in bank voles and from 0 to $24.6 \%$ in mice. These indices negatively correlated with the

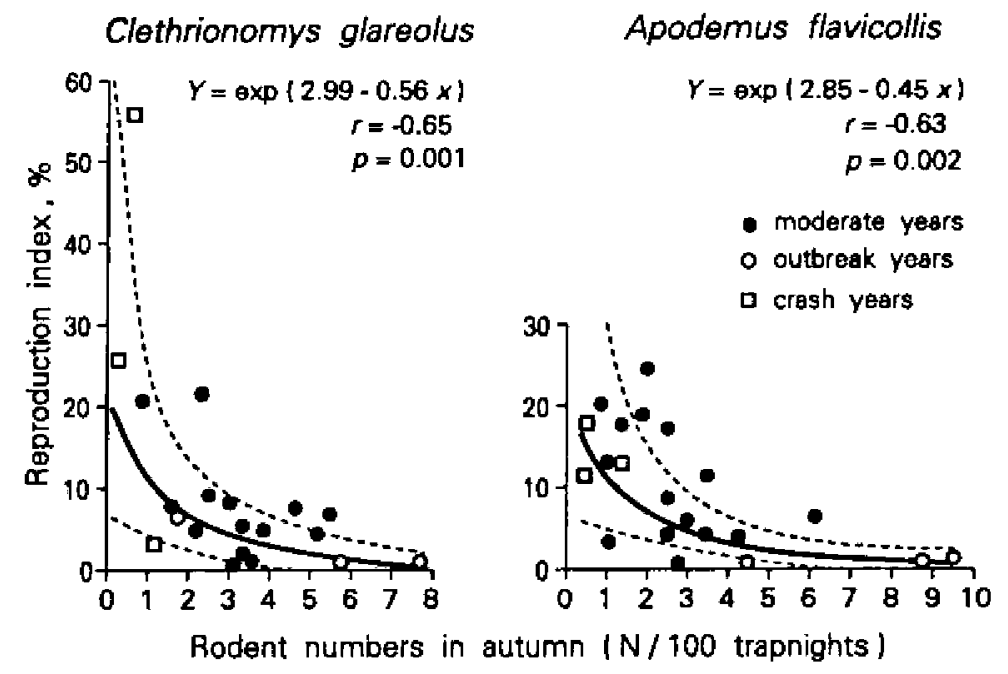

Fig. 11. Relationship between autumn (September) numbers of rodents and indices of their autumn reproduction. Reproduction index - numbers of females with visible pregnancies and the youngest juveniles ( $<11 \mathrm{~g}$ in bank voles, and $<14 \mathrm{~g}$ in yellow-necked mice) as percent of the total number of rodents in autumn. Regression lines include moderate, outbreak and crash years. 
respective indices of autumn numbers of rodents and were inversely density dependent (Fig. 11). Besides the density dependence, autumn reproduction of bank voles was strongly and positively correlated with high mean daily temperature of July - September $\left(R^{2}=64.2 \%, p<0.0005, n=21\right.$, multiple regression with autumn numbers and temperature as independent variables). Semipartial correlations showed, that in the whole series with extreme densities of outbreaks and crashes included, the autumn number of voles was more important in shaping autumn reproduction index $\left(s r^{2}=0.433\right)$, than the temperature in July - September $\left(s r^{2}\right.$ $=0.296$ ). In moderate years, temperature became the prime factor explaining the variation in the autumn reproduction index $\left(s r^{2}=0.483\right.$ for temperature, and $s r^{2}$ $=0.378$ for autumn numbers; $R^{2}=76.1 \%, p<0.0005, n=15$ ).

The index of autumn reproduction of mice was not affected by ambient temperature. Breeding intensity in autumn was governed primarily by mouse densities (Fig. 11). The seed crop of the current year (seeds begin to fall to the ground in September) only slightly enhanced mouse reproduction (multiple regression: $R^{2}=47 \%, p=0.006, n=21 ; s r^{2}=0.258$ for autumn numbers, and $s r^{2}$ $=0.086$ for hornbeam seed crop of the current year). In moderate years the same relationship, though not significant, was observed $\left(R^{2}=32.1 \%, p=0.119, n=14\right)$.

\section{Winter mortality of rodents}

In both species of rodents, winter mortality (calculated as the difference between the number of rodents trapped in a preceding autumn and in spring) was strictly density dependent: the autumn numbers of each species of rodents explained $99 \%$ of winter mortality of mice and $92 \%$ of voles (Fig. 12). The regression line of density dependent mortality in both species (particularly so in mice) was very close to the extinction line $Y=X$. Percent mortality of each species in relation to autumn numbers was compared to the expected curve calculated as the quotient of these two functions: empirical mortality regression line and extinction line (Fig. 12). At very low numbers in autumn, winter mortality approached zero. With the increase of densities, percent mortality rapidly grew very high. The higher the densities, the closer the mortality to extinction.

Table 3. Mean (SD) winter mortality of yellow-necked mice and bank voles (autumn numbers of rodents minus numbers of overwintered rodents in the following spring, expressed as percent of autumn numbers) in winters after mast fall, winters following the outbreaks, and all other winters. Values marked with an asterisk statistically differ from each other $\left(t_{\mathrm{B}}=2.27, p<0.05\right.$, Test for Two Means with Unequal Variances). 1 1976/77, 1982/83 in bank voles (no reliable data for 1989/90), and $1976 / 77,1982 / 83$, and $1989 / 90$ in mice; ${ }^{2} 1977 / 78,1983 / 84$, and $1990 / 91$.

\begin{tabular}{|c|c|c|}
\hline Winter & Yellow-necked mice & Bank voles \\
\hline Winters after mast fall $\mathbf{l}$ & $57 \%(25.4)$ & $72 \% \quad(5.2)$ \\
\hline Winters following outbreaks ${ }^{2}$ & $98 \%(2.6)^{*}$ & $93 \%(11.1)$ \\
\hline All other winters ( $n=15$ ) & $88 \%(12.7)^{*}$ & $75 \%(24.3)$ \\
\hline
\end{tabular}



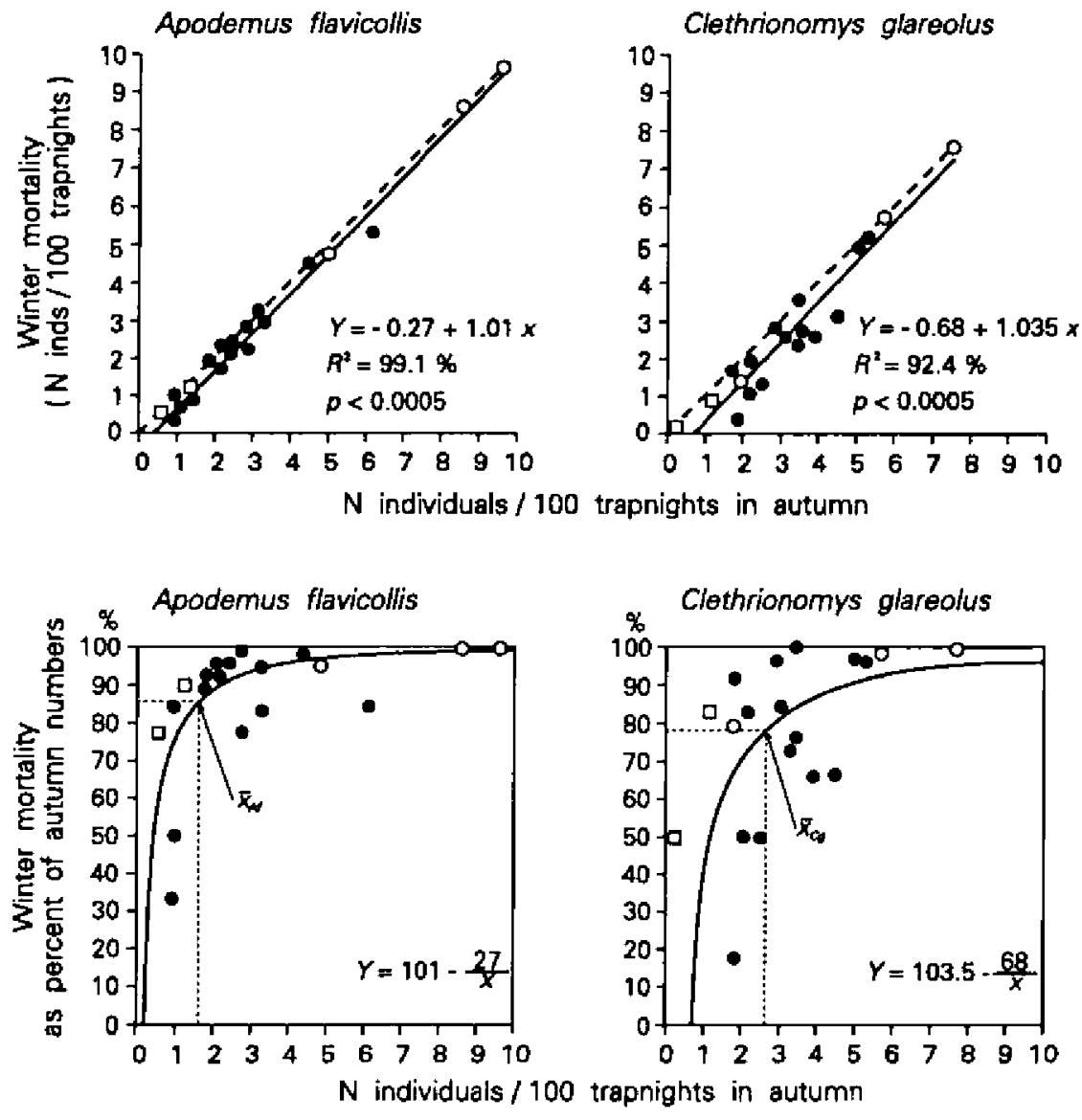

- moderate years, o outbreak years, a crash years

Fig. 12. Upper figures; winter mortality of yellow-necked mice and bank voles (calculated as diflerence between the numbers in autumn and numbers of overwintered adults in the following spring) in relation to autumn numbers of rodents. Data points for each winter except for $1989 / 90$ in bank voles (see Material and methods'). Regression lines include moderate, outbreak, and crash years. Dotted line $Y=X$ denotes the 'extinction line'. Lower figures: relationship between the percent winter mortality (winter mortality expressed as percent of autumn numbers) and the autumn numbers. Empirical data points are overlaid on the expected curves calculated as the quotients of the two functions from upper graphs: the empirical regression line and the 'extinction line' in each species. $\bar{x}_{C z}$ and $\bar{x}_{A f}-$ mean mortality of bank voles and yellow-necked mice, respectively.

In yellow-necked mice, seed crop and mean temperature in autumn - winter increased percent overwinter survival $\left(R^{2}=54 \%, p=0.002, n=19 ; s r^{2}=0.328\right.$ for hornbeam seed crop and $s r^{2}=0.078$ for the temperature), but this relationship was shaped by high mast years and was not significant for moderate years $\left(R^{2}=\right.$ $11 \%, p=0.56, n=13$ ) (Table 3). There was no correlation between percent winter mortality of mice and snow cover. 
The mortality of bank voles in moderate years was lowered significantly by snow cover $\left(R^{2}=67.2 \%, p=0.012, n=11\right)$, but during the outbreak-crash phases it did not correlate with snow cover. Mast supply did not improve winter survival of voles (Table 3).

\section{Recapitulation of results}

Populations of yellow-necked mouse and bank vole in BNP were characterized by wildly variable summer-autumn numbers and relatively little variation in spring numbers. Factors that were found to correlate with or determine various phases of rodent population dynamics are summarized in Table 4. Yellow-necked mouse numbers in summer were shaped by the number of overwintered adults in spring. The seed crop of the previous year determined the onset of breeding in spring (or even winter breeding) and the autumn numbers of mice. Outbreaks were the extreme cases of mouse response to heavy crops. The crashes, however, could not have been explained by the lack of seeds alone.

Numbers of bank voles were shaped by partly different factors than those of mice (Table 4). Population growth in summer was enhanced by higher temperature in June - July. Seed crop did not play a role unless superabundant. Crashes, that followed outbreaks caused by heavy crops, were usually deep and not explicable by either temperature or lack of seeds.

Intrapopulation mechanisms stabilizing the autumn numbers (i.e. density dependent restriction of autumn breeding) were seen in both species. They were, however, rather easily overridden by favourable environmental conditions (seed crop in mice, high ambient temperature in voles).

Very high, predictable and density dependent winter mortality was a prime factor driving vole and mouse numbers to lows every spring. Overwinter survival was somewhat improved by heavy seed crop in mice and deep snow (but only in moderate years) in bank voles.

The pattern of 2 years of outbreak and crash (induced by heavy seed crops) separated by $4-7$ years of moderate numbers, was still more clear at the community level than in each of the rodent species separately.

\section{Discussion}

\section{Regulation of rodent dynamies in a broadleaf forest}

Population dynamics of forest rodents in a broadleaf, oak-dominated forest in central Europe has a specific pattern. It has already been documented in other localities of lowland Europe, where heavy seed crops of oak and/or beech caused outbreaks of rodents (e.g. Newson 1963, Zablockaja 1971, Kudrjašova 1975, Jensen 1982). However, none of the earlier studies covered enough years to document the recurrence of the whole cycle and to evidence its regular character. The pattern 
Table 4. Regression and correlation analysis of population dynamicg parameters of yellow-necked mouse and bank vole, seed crop, and weather in Bialowieża National Park. Whole series - 1971 1991 (rodent and weather data - 21 years, hornbeam and maple seed crop - 19 years, oak and spruce seed crop - 16 years). Moderate years - moderate numbers of rodents, see Fig. 6 (15 years of rodent and weather data, 13 years of hornbeam seed crop data). Significance: --- or +t+ (negative or positive correlation) $p \leq 0.001 ;--$ or $++p \leq 0.01$; - or $+p \leq 0.05$; ns - not significant. Lack of any notation - regression or correlation not calculated (not pertinent). Data used for computation are listed in Appendices I - IV.

Abbreviations: (n) - current year, (n-1) - previous year; Arabic numerals denote months, e.g. 3 March, 7-10 - July through October, 11-3 - November through March; Seed - seed crop, Horn hornbeam, Map - maple, Oak - oak, Spru - spnice; Num - number of rodents/100 trapnights; Temp - mean daily temperature, Rain - mean dajly rainfall, Snow - mean daily snow cover; Win - winter, Spr - spring, Summ - summer, Aut - autumn; Ad - adults, Juv - juveniles; Repr - reproduction, Mort - mortality, Incr - increase in numbers; $\%$ - percentage. A.f. - Apodemus flavicollis; C.g. Clethrionomys glareolus.

\begin{tabular}{|c|c|c|c|c|}
\hline \multirow{2}{*}{$\begin{array}{l}\text { Dependent } \\
\text { variable }\end{array}$} & \multirow{2}{*}{$\begin{array}{l}\text { Independent } \\
\text { variable }\end{array}$} & \multicolumn{2}{|c|}{ Significance in: } & \multirow[t]{2}{*}{ Comments } \\
\hline & & whole series & moderate years & \\
\hline 1 & 2 & 3 & 4 & 5 \\
\hline \multicolumn{5}{|c|}{ Tree seed crop } \\
\hline HornSeed(n) & OakSeed(n) & +++ & & \\
\hline HornSeed(n) & MapSeed(n) & +++ & & \\
\hline HornSeed(n) & SpruSeed(n) & ns & & \\
\hline HornSeed(n) & Rain4-10(n) & - & & \\
\hline MapSeed(n) & Rain4-10(n) & - & & \\
\hline
\end{tabular}

\begin{tabular}{|c|c|c|c|c|}
\hline \multicolumn{5}{|c|}{ Apodemus /avicollis } \\
\hline WinRepr(A.f.) & HornSeed & & & $\begin{array}{l}\text { heavy mast caused } \\
\text { winter breeding }\end{array}$ \\
\hline NumAdSpr (A.f.) & $\%$ WinMort $(A . f)$ & --- & - & \\
\hline NumuJuvspr(A.f.) & HornSeed(n-1) & +++ & ns & \\
\hline NumJuvSpr(A.f.) & Temp(3) & + & ns & \\
\hline NumJuvSpr(A.f.) & NumAdSpr $(A, f)$. & $\mathrm{ns}$ & ns & \\
\hline $\operatorname{NumSumm}(A . f)$ & NumAdSpr $\left(A_{2} f.\right)$ & $++t$ & +++ & \\
\hline $\operatorname{NumSumm}(A . f)$ & HornSeed(n-1) & + & $\mathrm{ns}$ & \\
\hline NumSumm(A.f.) & $\operatorname{NumSumm}(C \cdot g)$. & + & + & \\
\hline $\operatorname{IncrAut}(A . f)$. & IncrSumm(A.f.) & ns & -- & \\
\hline $\operatorname{Incr} A u t(A . f)$ & HornSeed(n-1) & $\mathrm{ns}$ & ns & \\
\hline \multirow[t]{2}{*}{ IncrAut $(A . f)$} & $\operatorname{IncrSumm}(A . f)$. & & & \\
\hline & and HornSeed(n-1) & + & + & \\
\hline IncrAut(A.f.) & IncrAut $(C . g)$. & us & + & \\
\hline $\operatorname{NumAut}(A, f)$ & HornSeed(n-1) & + & + & \\
\hline NumAut(A.f.) & NumAut(C.g.) & ns & ns & \\
\hline \%eprAut(A.f.) & $\operatorname{NumAut}(A . f)$. & -- & ns & \\
\hline \%ReprAut(A.f.) & HornSeed(n) & + & ns & \\
\hline WinMort $(A . f)$ & $\operatorname{NumAut}(A, f)$. & +++ & +++ & \\
\hline$\%$ WinMort (A.f.) & HornSeed(n-1) & & & $\begin{array}{l}\text { heavy mast decreased } \\
\text { winter mortality }\end{array}$ \\
\hline $\mathscr{O}$ WinMort $(A, f)$ & Temp(11-3) & - & ng & \\
\hline \%WinMort(A.f.) & Snow & ns & ns & \\
\hline
\end{tabular}


Table 4 - concluded.

\begin{tabular}{|c|c|c|c|c|}
\hline 1 & 2 & 3 & 4 & 5 \\
\hline \multicolumn{5}{|c|}{ Clethrionomys glareolus } \\
\hline WinRepr $(C . g)$. & $\begin{array}{l}\text { HornSeed }(n-1) \\
\text { and Temp }(11-3)\end{array}$ & & & $\begin{array}{l}\text { heavy mast coinciding } \\
\text { with warm winter } \\
\text { caused winter breeding }\end{array}$ \\
\hline NumAdSpr(C.g.) & \%WinMort $(C . g)$. & - - & -- & \\
\hline NumJuvSpr(C.g.) & $\operatorname{Temp}(11-3)$ & + & + & \\
\hline NumSumm(C.g.) & NumAdSpr (C.g.) & + & ns & \\
\hline NumSumm(C.g.) & $\operatorname{Temp}(6-7)$ & + & + & \\
\hline NumSumm(C.g.) & HornSeed $(n-1)$ & + & ng & \\
\hline NumSumm(C,g.) & NumSumm(A.f.) & + & + & \\
\hline IncrAut $(C . g)$. & $\operatorname{IncrSumm}(C . g)$. & ns & - & \\
\hline IncrAut (C.g.) & HornSeed(n-1) & ns & ns & \\
\hline \multirow[t]{2}{*}{ IncrAut(C.g.) } & HornSeed $(n-1)$ & & & \\
\hline & and IncrSumm(C.g.) & + & ns & \\
\hline NumAut $(C . g)$. & NumAdSpr(C.g.) & + & ns & \\
\hline NumAut $(C, g)$. & HornSeed (n-1) & + & ns & \\
\hline \%ReprAut $(C, g)$. & NumAut $(C, g)$ & - & - & \\
\hline FReprAut (C.g.) & Temp(7-9) & + & + & \\
\hline WinMort(C.g.) & NumAut(C.g.) & +++ & ++ & \\
\hline gowinMort(C.g.) & Snow & $\mathrm{ns}$ & - & \\
\hline
\end{tabular}

of rodent population dynamics decribed in this paper may be called a 'recurrent wave' dynamics, in which the wave was induced by periodically excessive seed supply.

Outbreak densities of rodents after heavy mast production can reach and exceed those of cyclic microtines from northern Europe (Henttonen et al. 1987) or farmlands in Central Europe (Ryszkowski et al. 1973). Densities of bank voles in BNP varied from 3 to 25/ha in spring and from 8 to 147/ha in autumn (Gębczyńska 1966, Grodziński et al. 1966, Aulak 1973, Wójeik and Wołk 1985, Sikorski 1989 , Jędrzejewski et al. 1992, see review in Jędrzejewski and Jędrzejewska 1993). Densities of yellow-recked mice varied from $<1$ to $9 /$ ha in spring and from 6 to 120/ha in autumn (Gębczyńska 1966, Grodziński et al. 1966, W6jcik and Wołk 1985, Wołk and Kozłowski 1989, Wójcik 1993, Jędrzejewski et al. 1992, see review in Jędrzejewski and Jędrzejewska 1993). In Jutland, outbreak densities of bank voles after mast years reached 125/ha (Jensen 1982).

Four groups of factors, i.e. weather, food resources, predation, and social mechanisms played roles in regulating rodent numbers in Bialowieża and will be discussed below. Disease was not studied in BNP and its role in shaping rodent populations remains unknown.

What was the role of food resources in shaping the numbers of forest rodents in BNP? In the yellow-necked mouse, not only were the outbreaks triggered by superabundant food but also the autumn numbers in moderate years were largely 
determined by the seed crop in the previous year. However, seed supply had negligible effect on overwinter survival of mice; even superabundant mast reduced mortality of mice by only $30 \%$ (from 88 to $57 \%$ on average).

Seeds of trees are the predominant food resource for mice. In the total biomass of seeds produced by the pristine oak-lime-hornbeam stand, $99 \%$ are seeds of trees and only $<1 \%$ - seeds of herbs (Falińska 1971). In moderate years, the seed crop in pristine oak-lime-hornbeam stands of Białowieża Primeval Forest varied from 0 to $856.2 \mathrm{~kg} / \mathrm{ha}$, on average $329.3 \mathrm{~kg} / \mathrm{ha}$ (SD 291.4, $n=10$ study areas in 1947, 1948, 1968, 1969, 1975, 1977, 1978, and 1986) (Aulak 1970, Falińska 1971, Dackevic 1980, Faliński et al. 1988). In 2 mast years, the biomass of seeds was: in 1967 - 1,922 kg/ha in hombeam dominated stand (Falińska 1971); in 1976 $953.2 \mathrm{~kg} / \mathrm{ha}$ (acorn only) (Dackevix 1980). The fall of tree seeds begins in September, peaks in October, and continues in small quantities till the next spring (Falińska 1971). To take advantage of this food and to successfully compete with ungulates and squirrels, rodents have to hoard as much as possible of them till the next spring-summer (Ashby 1967) and to build body fat (Grodziński 1985).

In non-mast years, restricted seed supply was the prime reason for the seasonal (April through September) breeding of mice. Extra food (mast) always caused intense winter breeding, irrespectively of how harsh was the weather.

Bank vole numbers were influenced by seed supply less than those of yellow-necked mice. Could they be determined by varying abundance of green biomass? We did not study the green forage directly, but ambient temperature was an indirect measure of herbaceous biomass availability. Growth of herbaceous plant biomass under the dense canopy of deciduous forest has clearly seasonal pattern. Vegetation develops intensely in May and June, disappears fast in October, and in winter it amounts to only ca $10 \%$ of the maximum summer stand (Aulak 1973). The total biomass of herbs at its peak varied from $300 \mathrm{~kg} / \mathrm{ha}$ in summer with mean June - July temperature of $18^{\circ} \mathrm{C}(1971)$ to over $520 \mathrm{~kg} / \mathrm{ha}$ in summer with mean temp. of $20^{\circ} \mathrm{C}$ (1972) (Aulak 1976). Thus, the standing crop of herb biomass in mature deciduous forest is ca 10 times lower than that of open meadows in Central Europe (Medwecka-Kornas 1967).

Aulak (1973) showed that energy requirements of bank vole populations in winter constituted $13.5 \%$ of available green vegetation. Since numerous other herbivores (mainly ungulates) live in the forest, it seems that plant resources are not so excessively plentiful for voles as was suggested by earlier studies covering heavy mast years (Górecki and Gębczyńska 1962, Drożdż 1966, Bobek 1969).

This study showed that bank vole numbers were regulated by food availability at two levels. First, reproduction was synchronized with seasonal development of plants. Shortage of food was the reason why bank voles did not breed in winter. During very warm winters (e.g. 1974/75), the herb layer coverage reached up to $70 \%$ of the maximum summer coverage (see Falinski 1986, p. 240-241) and then voles began breeding earlier than in other years. Addition of extra seed food (as in 1989/90) made the voles reproduce intensively throughout winter. These results 
are consistent with earlier experiments with provision of extra food to bank voles (Andrzejewski 1975, Bujalska 1975).

Secondly, primary production of plants (shaped by temperature in June - July) affected the population growth of bank vole from spring to summer. This relationship was also shown in Sweden (Hansson 1979, Laine and Henttonen 1983, Hornfeldt et al. 1986). Food resources, however, did not shape winter mortality of bank voles (even a heavy seed crop did not reduce mortality) and could not explain the crash after outbreaks.

Winter mortality of both species of forest rodents was the main factor regulating their population dynamics through a regular and density-dependent force driving the rodent numbers very low each spring. Studies conducted in BNP in 1986/87 - 1988/89 documented that predation was the prime cause of winter mortality in voles and mice (Jędrzejewski and Jędrzejewska 1993). In those moderate years, from 1 October to 15 April, eight species of predators removed an average of 28 to 35 bank voles from 1 ha. Most important predators were two generalists, tawny owl Strix aluco (60\% of the total predation impact) and pine marten Martes martes (14\%), and one specialist, the least weasel Mustela nivalis (17\%). Stable autumn numbers of bank voles in the 3 years studied made it impossible to investigate whether predation was density dependent, but this was strongly suggested by studies (covering more years) on tawny owl and pine marten diets (Jędrzejewski and Jędrzejewska 1993). Predation impact on bank voles was mediated by snow cover, which decreased the efficiency of vole hunting by tawny owl and pine marten (Jędrzejewski and Jędrzejewska 1993). The role of snow in affecting predation impact on voles was consistent with the correlation between snow and rodent mortality found in this 21-year data set. It is also consistent with the earlier data of Formozov (1946), Naumov (1961), Sonerud (1986), Canova (1989) and Nybo and Sonerud (1990).

Predatory impact on yellow-necked mice was from 14 to $17 \mathrm{inds} / \mathrm{ha}$ and showed density dependence. Tawny owls were responsible for $70 \%$ of the total predation, pine marten for $10 \%$, and least weasels $-13 \%$. Snow cover did not modify predation on mice (Jędrzejewski and Jędrzejewska 1993).

The regulatory role of predation differed between seasons. Predators could not prevent the increase of rodents from spring to summer, because of (1) the intense reproduction of rodents and (2) the seasonally greatest abundance of alternative prey (birds, frogs). Predation may, however, have an indirect effect on summer numbers of mice, which depended on abundance of overwintered adults in spring. In autumn, food, social, and weather factors impeded reproduction of rodents, so the recruitment could no longer compensate for the mortality caused by predation. Availability of alternative prey decreases, and predators again take a heavy toll of rodents until the following spring. This is consistent with earlier studies on non-cyclic rodents by Erlinge et al. (1983), Erlinge (1987), Ryszkowski et al. (1973) and Goszczyński (1977) (two latter ones for forest rodents only). 
Regulation of rodent numbers by winter predation was facilitated by the lack of winter breeding in 17 out of 21 years. When mast triggered intense winter breeding of mice, predators were not as effective. In 3 such years $(1976 / 77,1982 / 83$, $1989 / 90$ ), recruitment compensated for mortality, and the spring numbers of mice (juveniles and adults) were on average $83 \%$ of the previous autumn numbers.

What was the role of predators in the outbreak-crash years of forest rodents in BNP? Although the estimates of predation during outbreak and crash are not yet available in our study area, some responses by predators were observed. They included: (1) functional (dietary) response of generalist predators (tawny owls, martens) and predators specializing on other prey (i.e. polecat Mustela putorius) (Jędrzejewski and Jẹdrzejewska 1993, Jędrzejewski et al. 1993, W. Jędrzejewski, B. Jędrzejewska and A. Zalewski, in prep.); (2) strong numerical response of least weasels to rodent outbreaks and their decline during crash year, both with no time lag (W. Jędrzejewski, B. Jędrzejewska and L. Szymura, in prep.). Predators, however, could not prevent the outbreaks. This was consistent with studies by Pearson (1966, 1971) on Microtus californicus, Ryszkowski et al. (1973) and Goszczyński (1977) on Microtus arvalis.

Rodent outbreaks in Białowieża Forest occasionally attracked northern nomadic owls, which, however, were of marginal importance in suppressing rodent numbers. The Tengmalm's owl Aegolius funereus, which is a rarely recorded breeder in Bialowieza Forest, was found in 27 sites in spring 1983. Snowy owls Nyctea scandiaca were recorded twice: in 1960 (after outbreak in 1959), and in 1977 (outbreak) (Tomiałoje 1990).

Although predators contributed to the quick decline of rodents after a peak, the role of disease in Białowieża remains unknown. Myasnikov and Levacheva (1963) documented that in oak forests in the Tula region (south of Moscow), the outbreak of bank voles in 1958 was followed by an epidemic spread of hemorragic fever in the local human population living or working in the forest in winter 1958/59. However, the bacteriological study of rodent population did not yield any evidence that disease was a cause of bank vole deaths (Panina and Myasnikov 1960).

Predation was an important factor shaping the low numbers after peaks and prolonging the crash phase in cyclic rodents (Pearson 1966, 1971, for Microtus californicus, Ryszkowski et al. 1973, Goszczyński 1977, for $M$. arvalis). In BNP, predation was most probably crucial in keeping rodent numbers low during the crash years; e.g. during winter 1991/92, weasels alone reduced the autumn density of rodents by $20 \%$ (W. Jędrzejewski, B. Jędrzejewska and L. Szymura, in prep.). Annually renewable phytomass resources made it unlikely, that the depletion of food by peak numbers of rodents would be the sole cause of the prolonged crash. However, the lack of crash in 1969 coinciding with very good crop of maple seeds and fair crop of acom in the previous year (see Figs 2 and 6) suggests that food shortage may also play a role. 
Density-dependent restriction of autumn breeding was observed in both mice and voles. Spacing behaviour of females and the suppression of maturation of young may prevent further breeding and growth of the population (Bujalska 1970, Montgomery and Gurnell 1985). In BNP, however, intrapopulation factors acted at outbreak densities of both species, when shortage of food might have been conducive to competitive interactions. At moderate densities, the social regulation was easily suppressed by good food conditions.

How general is the pattern of population dynamics presented here for forest rodents?

The oak-hornbea $m$ forests are currently the edaphic and climatic climax forests of lowlands in central Europe, characterized by subcontinental climate. Eastwards (beyond Dnestr river), as the climate becomes continental, a narrow belt of oak-lime forests stretches to the Ural Mountains. Westward, in the subatlantic climate, beech-oak forests dominate the natural vegetation. Westernmost Europe with an Atlantic climate was covered with oak-birch forests (Podbielkowski 1982). Thus, oaks (mainly Quercus robur and Q. petraea) were the keystone species of the European primeval forests from Atlantic to the Ural mountains. Most of those forests, however, have long been replaced by pastures, farmlands, heathlands and commercial coniferous (spruce and pine) forests (Mityk 1978). Since mature deciduous forests have survived as scattered, relic patches, it is difficult to reconstruct the course of ecological processes that occurred here. We found merely a dozen or so studies (ours included), describing seed crops and rodent population dynamics (bank voles, yellow-necked and wood mice) or only rodent populations, that were done in mature oak/beech forests. Although most of them were shurt-term studies, the clear pattern of a large-scale synchronization of heavy seed crops emerges. The most spectacular crops of 1958 (or 1957), 1967 (or 1968), 1976, 1982 and 1989 and/or the outbreaks of rodents in the following year were recorded concurrently in 2 to 6 localities over a maximum straight-line distance of $3,500 \mathrm{~km}$ (Fig. 13). In western and central Europe, beech and oak may additionally produce fairly good crops between the large mast years, as was recorded in 1964 in England (Smyth 1966) and Poland (Grodziński et al. 1966), in 1969 and 1974 in Denmark (Jensen 1982). At the same time, rodents inhabiting other types of forests show different dynamics of numbers (e.g. Andrzejewski 1963, Flowerdew 1985).

In western Europe, rodents are capable of allocating much of the superabundant energy from seeds into autumn-winter breeding, so the autumn numbers (immediately after seed fall) and numbers in the following spring are very high (Newson 1963, Ashby 1967, Jensen 1982; see also wood mice dynamics in Southern and Lowe 1982). Crashes were either not observed at all or seen after some outbreaks only. In central and eastern Europe, rodents reached maximum numbers in summer - autumn of the year following the mast (despite the fact that winter breeding after heavy mast was recorded even in the furthest east-north parts of oak forest zone; see Kudrjašova 1971) and crashes were usually well marked (Kudrjašova 1975, Myasnikov 1976, this study). Three factors may be involved in 


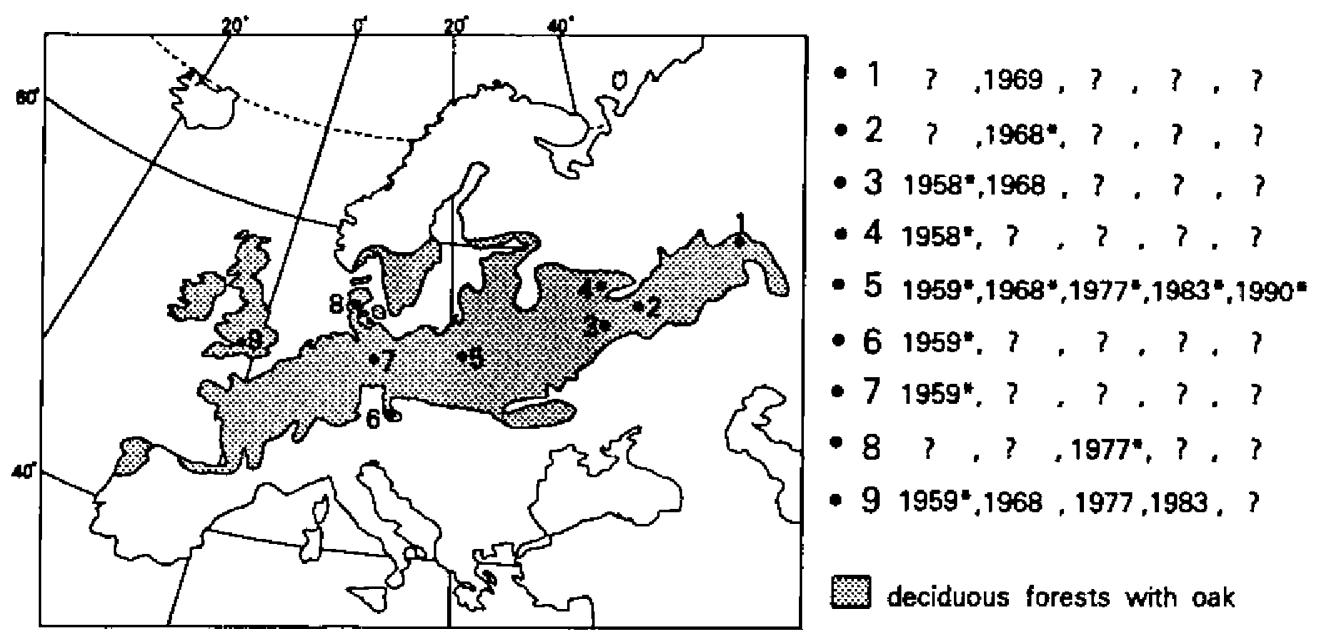

Fig. 13. Spatial synchronization of the 5 heaviest seed crops recorded in Bialowieza Primeval Forest. and other localities in the geographic range of European deciduous forests with oaks Quercus spp. Points and numbers (1-9) indicate places, where studies on seed crop and/or rodent dynamies were conducted. Years with asterisks - outbreak symptoms (winter breeding and/or exceptionally high numbers of rodents) following heavy seed crop; years with no asterisk - unusually high densities of rodents recorded, but no information on seed crop given. ? - no data. Sources: (1) Mari ASSR (north of Kazan), Dobrohotov et al. (1970); (2) Oka river catchment, Russia, Kudrjasova (1975); (3) Tula forests, Moscow region, Panina and Myasnikov (1960), Myasnikov (1976); (4) Prioksko-Terrasnyi Reserve, Russia, Zablockaja (1971); (5) this study; (6) Bohemia, Zejda (1961); (7) Germany, Kulicke (1960); (8) Jutland, Denmark, Jensen (1982); (9) Oxford region, England, Newson (1963), Southern and Lowe (1982), Flowerdew (1985).

these differences: Western Europe has (1) a milder climate, (2) more species of deciduous, seed-bearing trees, (3) severely impoverished or even exterminated predator communities. It is not possible to separate the effects of these factors without further studies. Also, the role of disease in shaping rodent numbers may vary geographically.

Hansson and Henttonen $(1985,1988)$ described the north-south gradient in the increasing stability of rodent populations in Europe. North of $61^{\circ} \mathrm{N}$ vole populations are cyclic, at $59-61^{\circ}-$ semi-cyclic, and below $59^{\circ}-$ non-cyclic. Moreover, Hansson (1987) emphasized that non-cyclic populations of granivorous and herbivorous-granivorous rodents may have outbreaks under conditions of extra food supply. As shown by our studies, within the original range of oak forests, forest rodents show stable population dynamics with recurrent waves of outbreak-crash induced by heavy seed crops. These outbreaks and crashes are characterized by all features indicative of northern 'true cycles', i.e.: great magnitude of fluctuations, winter breeding, high spring densities before peak numbers, and deep declines extending over the following year. The near extermination of oak/beach forests, and transformation of European forests into commercial spruce, pine or poplar stands deprived rodents of the periodic superabundance of seeds and annihilated the outbreaks. 


\section{Conclusions}

European broadleaf forests, dominated by oak, produce heavy crops of seeds at 6 - 9-year intervals, synchronized over eastern, central and western Europe and stimulated by warm June - July temperatures in the year of bud formation. Mast years supply superabundant food available to forest rodents from autumn through winter. This extra food causes winter breeding and outbreaks of rodents the following summer. Rapid winter declines and 1-year crashes of rodent numbers occur a year after the outbreak.

Years between consecutive heavy masts are characterized by moderate densities of forest rodents. In those years, numbers of rodents are regulated by food supply (largely determined by weather) in summer and density-dependent predation in winter. How much predation and disease are responsible for the rapid (overwinter) decline and 1-year crash of rodents two years after the mast remains to be studied.

The dichotomy between 'cyclic' and 'non-cyclic' rodent population dynamics need not correspond to populations or biogeographic regions [see discussion in Sandell et al. (1991) and Hansson (1991)]. In the pristine oldgrowth forests of Bialowieża, intermittent outbreak-crash 'cycles' of forest rodents are one of the effects of the recurrent wave of excessive energy flowing from producers (trees) to primary consumers (rodents) to predators.

Acknowledgements: Many thanks are due to Prof Dr J. B. Falinski for allowing us to use the materials on seed crop of hornbeam and maple collected by the Bialowieza Geobotanical Station of Warsaw University. Analysis of these data was done in the Lahoratory of Geobotanic Photointerpretation of this Station. Forest Administration in Bialowicza provided the data on acorn and cone purchase. $\mathrm{S}$. Buszko, L. Siemieniuk, J. Siemieniuk, W. Szpakowicz, W. Bajko, and A. Lrazkiewicz helped in collecting rodents, and L. Szuma and L. Szymura - in analysing the data. Mr. L. Siemieniuk provided invaluable help with collecting and computer input of meteorolngical data. K. Zub prepared the figures in Corcl-Draw prngram. Our special thanks are due to Drs J. Gliwicz, L. Hansson, and W. Z. Lidicker for their critical reading of and valuable comments on the earlier draft of this paper.

\section{References}

Adamczewska K. A. 1961. Intensity of reproduction of the Apodemus flavicollis (Melehior, 1834) during the period 1954-1959. Acta theriol. 5; $1-21$.

Alibhai S. K. and Gipps J. H. W. 1985. The population dynamics of bank vole. [In: The ecology of woodland rodents bank voles and wood mice. J. R. Flowerdew, J. Gurnell and J. H. W. Gipps, eds]. Symp. zool. Soc. Lond. 55: $277-313$.

Andrzejewski R. 1963. Processes of incoming, settlement and disappearance of individuals and variations in the number of small rodents. Acta theriol. 7: $169-213$.

Andrzejewski R. 1975. Supplementary lood and winter dynamics of bank vole populations. Acta theriol. 20: $23-40$.

Ashby K. R. 1967. Studies on the ecology of field mice and voles (Apodemus syluaticus, Clethrionomys glareolus and Microtus agrestis) in Hougall Wood, Durham. J. Zool., Lond. 152: 389 - 513.

Aulak W. 1970. Small mammal communitieg of the Białowieża National Park. Acta theriol. 15: $465-515$.

Aulak W. 1973. Production and energy requirements in a population of the bank vole in a deciduous forest of Circaeo-Alnetum type. Acta theriol. 18: 167 - 190. 
Aulak W. 1976. Development and production of ground flora in Tilio-Carpinetum Tracz. 1962 association as one of the elements of basic trophic level in the forest ecosystems. Zeszyty Naukowe SGGW-AR w Warszawie, Rozpr. Nauk, 60: 1 - 151. [In Polish with English summary]

Bengtson S.-A., Nilsson A. and Rundgren S. 1989a. Population structure and dynamies of wood mouse Apodemus syluaticus in Iceland. Holarctic Ecol. 12: $351-368$.

Bengtson S.A., Nilsson A. and Rundgren S. 1989b. Unforseen disruption of wood mouse population dynamics after food reduction: a field experiment. Oikos 56: $379-385$.

Bobek B. 1969. Survival, turnover and production of small rodents in a beech forest. Acta theriol. 14: $191-210$.

Bujalska G. 1970. Reproduction stabilizing elements in an island populations of Clethrionomys glareolus (Schreber, 1780). Acta theriol. 15: $381-412$.

Bujalska G. 1975. The effect of supplementary food on some parameters in an island population of Clethrionomys glareolus (Schreber, 1780). Bull. Aced. pol. Sci., Ser. Sci. Biol. 23: 23 - 28.

Canova L. 1989. Influence of snow cover on prey selection by Long-eared ow]s Asio otus. Ethol. Ecol. Evol. 1: $367-372$.

Dackevic A. U. 1980. Plodonošnie duba i ego sputnikov v Belovežskoi Pušce [Seed production by oak and its satellites in the Belovexa Primeval Forest]. Zapovedniki Belorussii 4: $14-21$. [In Russian]

Dobrohotov B. P., Kovalevski Yu. V., Zukov V. I. and Mosolov L. P. 1970. The numerical abundance of small rodents in the autumn 1969; prognosis for 1970 of their epizootic status as vectors of tularemia in the RSFSR. Bjul. Mosk. Obsx. Ispyt. Prir., Otd. biol. 75(6): 46 - 55. [In Russian with English summary]

Drozdz A. 1966. Food habits and food supply of rodents in beech forest. Acta theriol. 11: $363-384$.

Erlinge S. 1987. Predation and cyclicity in a microtine population in southern Sweden. Oikos 50: $347-352$.

Erlinge S., Goransson G., Hansson L., Hogstedt G., Liberg O., Nilsson I. N., Nilsson T., von Schantz T., and Sylven M. 1983. Predation as a regulating factor on small rodent populations in southern Sweden. Oikos 40: 36 - 52 .

Erlinge S. Goransson G., Hogstedt G., Jansson G., Liberg O., Loman J., Nilsson I. N., von Schantz T. and Sylven M. 1984. Can vertebrate predators regulate their prey? Am. Nat. 123: 125 - 133.

Falinska K. 1971. An estimate of djaspore production in the ecosystem of a mixed oak-hornbeam forest (Querco-Carpinetum) in the Białowieza National Park. Ekol. pol. 29: 525 - 561.

Falinski J. B. 1977. Research on vegetation and plant population dynamics. Phytocoenosis 6 (1/2): $62-63$.

Falifiski J. B. 1986. Vegetation dynamics in temperate lowland primeval forests. Geobotany 8: 1 - 537. Dr W. Junk Publishers, Dordrecht.

Falifiski J. B., Canullo R. and Biały K. 1988. Changes in herb layer, litter fall and soil properties under primary and secondary tree stands in a deciduous forest ecosystem. Phytocoenosis - Biul. Fitosocjol. 1(NS): $1-49$.

Flowerdew J. R. 1985. The population dynamics of wood mice and yellow-necked mice. [In: The ecology of woodland rodents bank veles and wood mice. J. R. Flowerdew, J. Gurnell and J. H. W. Gipps, eds]. Symp. zool. Soc. Land. 55: $315-338$.

Formozov A. N. 1946. Snežnyi pokrov kak faktor sredy, ego znacenie v żizni mlekopitajušcih i ptic SSSR. [Snow cover as a integra] factor of the environment and its importance in the ecology of mammals and birds]. Materialy k poznaniju Fauny i Flory SSSR, Novaja Ser, Otd. zool. 5 (20): $1-141$. Izd. Mosk. Obsc. Ispyt. Prirody, Moskva. [In Russian]

Gepbczynska Z. 1966. Estimation of rodents numbers in a plot of Querceto-Carpinetum forest. Acta theriol. 11: $315-328$.

Gębczyńska Z. 1976. Food habits of the bank vole and phenological phases of plants in an oak hornbeam forest. Acta theriol. 21: 223 - 236.

Gliwicz J. 1988. Seasonal dispersal in non-cyclic populations of Clethrionomys glareolus and Apodemus favicollis. Acta theriol. 33: $263-272$. 
Goszczyfiski J. 1977. Connections between predatory birds and mammals and their prey. Acta theriol. 22: $399-430$

Górecki A. and Gębczyńska Z. 1962. Food conditions for small rodents in a deciduous forest. Acta theriol. 6: $275-295$.

Grodzinsski W. 1985. Ecological energetics of bank voles and wood mice. [In: The ecology of woodland rodents bank voles and wood mice. J. R. Flowerdew, J. Gurnell and J. H. W. Gipps, eds]. Symp. zool. Soc. Lond. 55: $169-192$.

Grodzifiski W., Pucek Z. and Ryszkowski L. 1966. Estimation of rodent numbers by means of prebaiting and intensive removal. Acta theriol. 11: $297-314$.

Hansgon L. 1971. Small rodent food, feeding and population dynamics. A comparison between granivorous and herbivorous species in Scandinavia. Oikos 22: $183-198$.

Hansson L. 1979. Food as a limiting factor for small rodent numbers - test of two hypotheses. Oecologia (Berl.) 37: 297 - 314 .

Hansson L. 1987. An interpretation of rodent dynamics as due to trophic interactions. Oikos 50: $308-318$.

Hansson L. 1991. Levels of density variations: the adequacy of indices and chaos. Oikos 61: 285-287.

Hansson L. and Henttonen H. 1985. Gradients in density variations of small rodents: the importance of latitude and snow cover. Oecologia (Berl.) 67: $394-402$.

Hansson L. and Henttonen H. 1988. Rodent dynamics as community processes. Trends Ecol. Evol. 3: $195-200$.

Henttonen $H_{\text {., }}$ Oksanen T., Jorttika A. and Haukisalmi V. 1987. How much do weasels shape microtine cycles in the northern Fennoscandian taiga? Oikos 50: $353-365$.

Hornfeldt B., Lofgren O. and Carlsson B.-G. 1986. Cycles in voles and small game in relation to variations in plant production indices in Northern Sweden. Oecologia (Berl.) 68: 496 - 502.

Jensen T. S. 1982. Seed production and outbreaks of non-cyclic rodent populations in deciduous forests. Oecologia (Berl.) 54: $184-192$.

Jẹdrzejewski W. and Jęrzejewska B. 1993. Predation on rodents in Bialowicta Primeval Forest, Poland. Ecography 16: $47-64$.

Jędrzejewski W., Jędrzejewska B. and McNeish E. 1992. Hunting success of the weasel Mustela nivalis and escape tactics of forest rodents in Białowieza National Park. Acta theriol. 37; $319-328$.

Jędrzejewski W., Jędrzejewska B. and Brzeziński M. (1993). Winter habitat selection and feeding habits of polecats (Mustela putorius) in the Białowieza National Park, Poland. Z. Sảugetierk. 58: $75-83$.

Kudrjašva L. M. 1971. Podsnežnoe razmnoženie ryžei polevkí v poimennyh dubravah Okskogo zapovednika zimoi $1967 / 68 \mathrm{~g}$. [Subnivean reproduction of the bank vole in river-side oak forests in the Oka River Reserve in winter 1967/68]. Ekologija 2:84-87. [In Russian]

Kudrjašva L. M. 1975. Dvið̌enie đislennosti naselenija ryzei polevki v okskoi poime v $1967-1973 \mathrm{gg}$ [Changes of numbers of bank vole population in Oka river catchment in 1967 - 1973]. Trudy Okskogo gos. Zapovednika, 11: 234 - 254. [In Russian]

Kulicke H. 1960. Wintervermehrung von Rotelmaus (Clethrionomys glareolus), Erdmaus (Microtus agrestis) und Gelbha]smaus (Apodemus flavicollis). Z. Säugetierk. 25: 89 - 98.

Laine $K$. and Henttonen $H$. 1983 . The role of plant production in microtine cycles in northern Fennoscandia. Oikos 40: 407-418.

Medwecka-Kornas A. (Ed) 1967. Studia ekosystemów lasu bukowego i łaki w Ojcowskim Parku Narodowym. Studia Naturae. Ser. A, 1: $61-90$.

Mityk J. 1978. Geografia fizyczna częsei swiata. (Zarys fizjograficzny). PWN-Polish Scientific Publishers, Warszawa: $1-502$.

Montgomery W. J. and Gurnell J. 1985. The behaviour of Apodemus. [In: The ccology of woodland rodents bank voles and wood mice. J. R. Flowerdew, J. Gurnell and J. H. W. Gipps, eds]. Symp. zool. Soc. Lond. 55: $89-115$. 
Myasnikov Yu. A. 1976. The distribution and population dinamics of rodents, Lagomorpha and insectivores species in the Tulskaya Oblast. Fauna and Ecology of Rodents 13: $164-236$. [In Russian with English summary]

Myasnikov Yu. A. and Jevacheva Z. A. 1963. On the geography of natural nidi infection in the Tula region. Bjul. Mosk. Obsc. Ispyt. Prirody (Otd. Biol.) 68 (1): 6 - 15. [In Russian with English summary]

Naumov N. P. 1961. Ekologia zwierzat. [Ecology of animals]. PWRiL, Warszawa: 1 - 532. [In Po]ish]

Newson R. 1963. Differences in numbers, reproduction and survival between two neighbouring populations of bank voles (Clethrionomys glareolus). Ecology 44: 110-120.

Nybo J. O. and Sonerud G. A. 1990. Seasonal changes in diet of Hawk Owls Surnia ulula: importance of snow cover. Ornis fennica $67: 45-51$.

Olszewski J. L. 1986. The role of forest ecosystems in modifying local climate of the Białowieza Primeval Forest, as revealed by air temperature characteristics. Prace habilitacyjne, Ossolineum, Wrociaw: 1 - 222. [In Polish with English summary]

Panina T. V. and Myasnikov Yu. A. 1960. On the population dynamics and reproduction of the vole Clethrionomys glareolus Schreb. in natural homes of hemorragic fever with kidney syndrom in Tula region. Zool. Z. 39: 1707 - 1715. [In Russian with English summary]

Pearson O. P. 1966. The prey of carnivores during one cycle of mouse abundance. J. Anim. Ecol. 35: $217-233$.

Pearson O. P. 1971. Additional measurements of the impact of carnivores on California voles (Microlus californicus). J. Mammal. 52: 41 - 49.

Podbielkowski Z. 1982. Roslinnosé kuli ziemskiej [Vegetation of the Planet]. Wyd. Szkolne i Pedag. Warszawa, 1 - 280. [In Polish]

Pucek M. 1983. Habitat preference. [In: Ecology of the bank vole. K. Petrusewicz, ed]. Acta theriol. 28, Suppl. 1: $31-40$.

Pucek Z. (Ed.) 1981. Keys to vertabrates of Poland. Mammals. PWN - Polish Scientific Publishers, Warszawa: $1-366$.

Pucek Z. and Zejda J. 1968. Technique of determining age in the red backed vole, Clethrionomys glareolus (Schreber, 1780). Small Mammal. News]. 2: $51-60$.

Raczyfiski J. 1983. Taxonomic position, geographical range and the ecology of distribution. [In: Ecology of the bank vole. K. Petrusewicz, ed.]. Acta theriol. 28, Suppl. 1: $66-75$.

Ryszkowski L., Goszczyński J. and Truszkowski J. 1973. Trophic relationships of the common vole in cultivated fields. Acta theriol. 18: 125 - 165.

Sandell M., Astrom M., Atlegrim O., Danell K., Edenius L., Hjalten J., Lundberg P., Palo T., Pettersson R. and Sjoberg G. 1991. 'Cyclic' and 'non-cyclic' small mammal populations: an artificial dichotomy. Oikos 61: $281-284$.

Sikorski M. D. 1989. System kojarzenia sie i charakterystyka sukcesu reprodukcyjnego w naturalnej populacji nornicy rudej. [Mating system and reproduction success in a free-living population of bank vole]. PhD Thesis, Mammal Research Institute, PAS, Białowieza: $1-40$. [In Polish]

Smyth M. 1966. Winter breeding in woodland mice, Apodemus sylvaticus, and voles, Clethrionomys glareolus and Microlus agrestis, near OxFord. J. Anim. Ecol. 35: 471-485.

Sonerud G. A. 1986. Effect of snow cover on seasonal changes in diet, habitat, and regional distribution of raptors that prey on small mammals in boreal zones of Fennoscandia. Holarctic Ecol. 9: $33-47$.

Southern H. N. and Lowe V. P. W. 1982. Predation by tawny owls (Strix aluco) on bank voles (Clethrionomys glareolus) and wood mice (Apodemus syluaticus). J. Zool., Lond. 198: 83 - 102.

Tomiatoje L. 1990. The birds of Poland. Their distribution and abundance. PWN - Polish Scjentific Publishers, Warszawa: 1 - 426. [In Polish with English summary]

Wołk E. and Kozłowski J. 1989. Changes of body weight and hematological parameters in a fluctuating population of Apodemus flavicollis. Acta theriol. 34: $439-464$. 
Wojcik A. M. 1993. Genetic variation in a fluctuating population of the yellow-necked mouse Apodemus Ravicollis. Acta theriol. 38 (4) (in print).

Wójcik J. M. and Wolk K. 1985. The daily activity rhythm of two competitive rodents: Clethrionomys glareolus and Apodemus flavicollis. Acta theriol. 30: 241 - 258.

Zablockaja L. V. 1971. Dinamika vidovoi struktury populjacii myševidnyh gryzunov v priokskih borah Moskovskoi oblasti [Dynamics of species structure of small rodents in the coniferous forests near Oka river, Moscow region]. Trudy Prioksko-Terrasnogo gos. Zapovednika 5: 146 - 160. [In Russian]

Zejda J. 1961. Age structure in populations of the bank vole, Clethrionomys glareolus Schreber, 1780 . Zool. Listy 10: $249-264$.

Zemanek M. 1972. Food and feeding habits of rodents in a deciduous forest. Acta theriol. 17: $315-325$.

Received 18 January 1993, accepled 19 June 1993.

\section{Appendices}

Appendix I. Indices of yellow-necked mouse Apodemus /avicollis numbers ( $n$ inds/100 trapnights) in oak-lime-hornbeam forest in Białowicza National Park in 1971 - 1991. Spring - April/May, summer - July, autumn - September/October.

\begin{tabular}{|c|c|c|c|c|c|}
\hline Year & $\begin{array}{l}\text { Overwintered } \\
\text { adults } \\
\text { in spring }\end{array}$ & $\begin{array}{c}\text { Juveniles } \\
\text { in spring } \\
(\leq 24 \mathrm{~g})\end{array}$ & $\begin{array}{l}\text { All mice } \\
\text { in su mmer }\end{array}$ & $\begin{array}{l}\text { All mice } \\
\text { in autumn }\end{array}$ & $\begin{array}{l}\text { Youngest juveniles } \\
\text { ( }<14 \mathrm{~g} \text { ) and females } \\
\text { with visible preg- } \\
\text { nancies in autumn }\end{array}$ \\
\hline 1971 & 0.032 & 0 & 0.572 & 2.444 & 0.190 \\
\hline 1972 & 0.095 & 0.063 & 1.016 & 2.794 & 0 \\
\hline 1973 & 0.032 & 0 & 0.508 & 2.444 & 0.412 \\
\hline 1974 & 0.127 & 0.159 & 1.746 & 1.016 & 0.126 \\
\hline 1975 & 0.508 & 0.317 & 2.666 & 2.826 & 0.158 \\
\hline 1976 & 0.603 & 0.095 & 3.492 & 3.334 & 0.350 \\
\hline 1977 & 0.540 & 0.540 & 1.810 & 9.620 & 0.096 \\
\hline 1978 & 0.063 & 0 & 0.318 & 0.551 & 0.098 \\
\hline 1979 & 0.127 & 0 & 1.682 & 1.933 & 0.363 \\
\hline 1980 & 0.127 & 0 & 0.902 & 4.483 & 0.161 \\
\hline 1981 & 0.095 & 0 & 1.174 & 2.380 & 0.096 \\
\hline 1982 & 0.095 & 0.095 & 0.318 & 0.952 & 0.190 \\
\hline 1983 & 0.635 & 0.571 & 5.524 & 4.920 & 0 \\
\hline 1984 & 0.254 & 0 & 0.476 & 1.270 & 0.158 \\
\hline 1985 & 0.127 & 0.063 & 0.920 & 6.158 & 0.350 \\
\hline 1986 & 0.857 & 0 & 5.125 & 1.976 & 0.486 \\
\hline 1987 & 0.190 & 0 & 1.238 & 3.284 & 0.132 \\
\hline 1988 & 0.222 & 0 & 1.146 & 1.033 & 0.033 \\
\hline 1989 & 0.159 & 0.063 & 1.778 & 1.322 & 0.231 \\
\hline 1990 & 0.603 & 0.571 & 7.302 & 8.634 & 0 \\
\hline 1991 & 0.063 & 0 & 0.286 & 0.571 & 0.063 \\
\hline
\end{tabular}


Appendix II. Indices of bank vole Clethrionomys glareolus numbers ( $n$ inds/100 trapnights) in oak-lime-hornbeam forest in Białowieza National Park in 1971 - 1991. Months of trapping as in Appendix I.

\begin{tabular}{lclllc}
\hline Year & $\begin{array}{c}\text { Overwintered } \\
\text { adults } \\
\text { in spring }\end{array}$ & $\begin{array}{c}\text { Juveniles } \\
\text { in spring } \\
\text { (M } \begin{array}{l}\text { 1 root length } \\
<0.15 \mathrm{~mm})\end{array}\end{array}$ & $\begin{array}{c}\text { All voles } \\
\text { in summer }\end{array}$ & $\begin{array}{c}\text { All voles } \\
\text { in autumn }\end{array}$ & $\begin{array}{c}\text { Youngest juvenileg } \\
(<11 \text { g) and females } \\
\text { with visible preg- } \\
\text { nancies in autu mn }\end{array}$ \\
\hline 1971 & 0.380 & 0 & 2.254 & 5.270 & 0.286 \\
1972 & 0.222 & 0 & 4.158 & 5.080 & 0.126 \\
1973 & 0.190 & 0.032 & 2.888 & 2.920 & 0.222 \\
1974 & 0.096 & 0 & 1.810 & 1.778 & 0.126 \\
1975 & 0.158 & 0.064 & 2.254 & 2.254 & 0.476 \\
1976 & 0.350 & 0 & 3.142 & 3.556 & 0.032 \\
1977 & 0.858 & 0.032 & 3.302 & 1.874 & 0.126 \\
1978 & 0.380 & 0 & 1.206 & 1.134 & 0.033 \\
1979 & 0.190 & 0 & 1.238 & 3.101 & 0 \\
1980 & 0.437 & 0 & 0.628 & 3.483 & 0.065 \\
1981 & 0 & 0 & 1.810 & 2.508 & 0.222 \\
1982 & 1.270 & 0 & 2.762 & 4.540 & 0.318 \\
1983 & 1.430 & 0 & 4.572 & 7.714 & 0.032 \\
1984 & 0.064 & 0 & 0.096 & 0.126 & 0.032 \\
1985 & 0.064 & 0 & 0.826 & 2.126 & 0.096 \\
1986 & 1.080 & 0 & 5.093 & 1.880 & 0.065 \\
1987 & 1.556 & 0 & 2.412 & 3.948 & 0.132 \\
1988 & 1.334 & 0 & 2.453 & 3.421 & 0.128 \\
1989 & 0.952 & 0 & 2.286 & 0.793 & 0.164 \\
1990 & 3.366 & 1.588 & 4.190 & 5.746 & 0 \\
1991 & 0.064 & 0 & 0.286 & 0.286 & 0.159 \\
\hline & & 0 & & &
\end{tabular}


Appendix III. Indices of tree seed crop in Białowieża Primeval Forest. Hornbeam Carpinus betulus and maple Acer platanoides - mean number of seeds per $10 \mathrm{~m}^{2}$ of forest floor in oak-lime-hornbeam oldgrowth in Bialowieza National Park; oak Quercus robur and spruce Picea abies - total annual purchase (kg) of acorn and cones by Bjałowieza Forest Administration. ? - no data.

\begin{tabular}{lccrr}
\hline Year & $\begin{array}{c}\text { Hornbeam } \\
\left(n / 10 \mathrm{~m}^{2}\right)\end{array}$ & $\begin{array}{c}\text { Maple } \\
\left(n / 10 \mathrm{~m}^{2}\right)\end{array}$ & $\begin{array}{c}\text { Oak } \\
(\mathbf{k g})\end{array}$ & $\begin{array}{c}\text { Spruce } \\
(\mathbf{k g})\end{array}$ \\
\hline 1972 & 0.507 & 0 & $?$ & $?$ \\
1973 & 0 & 0.144 & $?$ & $?$ \\
1974 & 0.274 & 0.123 & $?$ & $?$ \\
1975 & 0.213 & 0.069 & 4,690 & 0 \\
1976 & 11.386 & 0.528 & 15,253 & 13,985 \\
1977 & 0.027 & 0.096 & 0 & 16,595 \\
1978 & 2.133 & 0.123 & 3,276 & 300 \\
1979 & 0.693 & 0.062 & 0 & 10,410 \\
1980 & 0.082 & 0 & 0 & 12,700 \\
1981 & 0.062 & 0 & 50 & 14,350 \\
1982 & 18.093 & 0.604 & 50,100 & 0 \\
1983 & 0.055 & 0 & 0 & 5,301 \\
1984 & 3.711 & 0.041 & $?$ & $?$ \\
1985 & 1.626 & 0.041 & 736 & 0 \\
1986 & 2.476 & 0.055 & 7,763 & 0 \\
1987 & 1.536 & 0.096 & 0 & 1,910 \\
1988 & 0.021 & 0.048 & 2,400 & 2,460 \\
1989 & 7.010 & 0.110 & 8,120 & 7,055 \\
1990 & 0.357 & 0.027 & 0 & 880 \\
\hline
\end{tabular}


Appendix IV. Weather data from Białowieza Primeval Forest in 1971 - 1991. Tw - mean daily temperature in autumn-winter (1 November - 31 March), denoted under the year of March; $T_{n}$ - mean daily temperature in spring-summer (1 April - 31 October); $\mathrm{T}_{3}$ - mean daily temperature in March; $\mathrm{T}_{6-7}$ - mean daily temperature in June - July; $\mathrm{T}_{7.9}$ - mean daily temperature in July - September; all measures of temperature in ${ }^{\circ} \mathrm{C}$. Rain - mean daily rainfall in spring - summer (1 April - 30 October) (mm); snow - mean daily snow cover in autumn-winter (1 November - $30 \mathrm{March})(\mathrm{mm})$, denoted under the year of March.

\begin{tabular}{|c|c|c|c|c|c|c|c|}
\hline Year & $\mathrm{T}_{\mathrm{w}}$ & $\mathrm{T}_{\mathrm{B}}$ & $\mathbf{T}_{3}$ & $T_{6-7}$ & $T_{7-9}$ & Rain & Snow \\
\hline 1971 & -1.14 & 13.91 & -1.37 & 18.18 & 16.60 & 1.91 & 89.6 \\
\hline 1972 & -1.41 & 13.84 & 1.92 & 19.97 & 16.98 & 2.97 & 61.0 \\
\hline 1973 & 0.17 & 13.01 & 2.60 & 18.00 & 16.01 & 2.25 & 18.9 \\
\hline 1974 & -0.31 & 12.61 & 2.82 & 16.03 & 15.99 & 3.18 & 86.5 \\
\hline 1975 & 1.58 & 14.47 & 3.86 & 18.57 & 17.73 & 2.86 & 9.6 \\
\hline 1976 & -2.71 & 12.50 & -2.32 & 17.34 & 15.58 & 1.68 & 132.0 \\
\hline 1977 & -0.10 & 12.70 & 3.33 & 17.37 & 14.34 & 2.36 & 84.0 \\
\hline 1978 & -1.21 & 12.29 & 2.24 & 16.49 & 14.61 & 2.27 & 190.3 \\
\hline 1979 & -3.17 & 13.30 & 0.57 & 17.91 & 15.13 & 2.44 & 306.4 \\
\hline 1980 & -2.48 & 12.33 & -3.40 & 16.92 & 15.21 & 3.19 & 102.3 \\
\hline 1981 & -1.17 & 13.84 & 2.07 & 18.79 & 16.56 & 2.14 & 38.7 \\
\hline 1982 & -1.53 & 13.87 & 2.33 & 17.68 & 17.48 & 1.52 & 112.8 \\
\hline 1983 & 1.22 & 14.77 & 2.59 & 18.15 & 17.17 & 1.74 & 25.0 \\
\hline 1984 & -0.96 & 13.70 & 0.14 & 15.88 & 15.90 & 2.41 & 56.4 \\
\hline 1985 & -4.54 & 13.52 & -0.10 & 16.58 & 15.85 & 2.27 & 100.2 \\
\hline 1986 & -2.66 & 13.75 & 0.91 & 18.35 & 15.44 & 2.02 & 193.7 \\
\hline 1987 & -3.76 & 12.86 & -4.00 & 18.02 & 15.36 & 1.56 & 196.4 \\
\hline 1988 & -0.22 & 13.94 & -0.10 & 18.91 & 16.97 & 2.42 & 82.1 \\
\hline 1989 & 1.22 & 14.40 & 4.59 & 18.13 & 16.72 & 1.70 & 24.0 \\
\hline 1990 & 2.23 & 13.33 & 5.97 & 17.19 & 14.80 & 2.18 & 19.4 \\
\hline 1991 & 0.02 & 13.84 & 2.81 & 18.60 & 17.49 & 1.30 & 40.9 \\
\hline
\end{tabular}

BAlowieza - ZAKLAD BADANIa SSAKów PAN - POLAND

Naklad $950+50$ egz. Obj. ark. wyd. 10,50 Obj. ark. druk. 7,50 Podpisano do druku w czerwcu $1993 . \quad$ Druk ukoficzono w lipeu 1993.

Sklad, tamanie, diapozytywy: Zaklad Badania Ssaków PAN, Bialowieża Druk: Bialostockie Zaklady Graficzne w Bialymstoku. 